\title{
Glycosaminoglycans Regulate CXCR3 Ligands at Distinct Levels: Protection against Processing by Dipeptidyl Peptidase IV/CD26 and Interference with Receptor Signaling
}

\author{
Mieke Metzemaekers ${ }^{1}$, Anneleen Mortier ${ }^{1}$, Rik Janssens ${ }^{1,2}$, Daiane Boff ${ }^{1,2}$, Lotte Vanbrabant ${ }^{1}$, \\ Nicole Lamoen ${ }^{3,+}$ (D) Jo Van Damme ${ }^{1}$, Mauro M. Teixeira ${ }^{2}$, Ingrid De Meester ${ }^{3}$, Flávio A. Amaral ${ }^{2}$ \\ and Paul Proost ${ }^{1, *}$ \\ 1 Laboratory of Molecular Immunology, Department of Microbiology and Immunology, \\ Rega Institute for Medical Research, KU Leuven, Herestraat 49 box 1042, B-3000 Leuven, Belgium; \\ mieke.metzemaekers@kuleuven.be (M.M.); anneleen_mortier@hotmail.com (A.M.); \\ rik.janssens@kuleuven.be (R.J.); daianebff@gmail.com (D.B.); lotte.vanbrabant@kuleuven.be (L.V.); \\ jo.vandamme@kuleuven.be (J.V.D.) \\ 2 Imunofarmacologia, Departamento de Bioquímica e Imunologia, Instituto de Ciências Biológicas, \\ Universidade Federal de Minas Gerais, Av Antonio Carlos 6627, Pampulha, Belo Horizonte 31270-901, \\ Minas Gerais, Brazil; mmtex.ufmg@gmail.com (M.M.T); dr.famaral@gmail.com (F.A.A.) \\ 3 Laboratory of Medical Biochemistry, Department of Pharmaceutical Sciences, University of Antwerp, \\ Universiteitsplein 1 S6, B-2610 Wilrijk, Belgium; ingrid.demeester@uantwerpen.be \\ * Correspondence: paul.proost@kuleuven.be; Tel.: +32-163-224-71 \\ + Nicole Lamoen passed away a few months ago.
}

Received: 7 June 2017; Accepted: 6 July 2017; Published: 13 July 2017

\begin{abstract}
CXC chemokine ligand (CXCL)9, CXCL10 and CXCL11 direct chemotaxis of mainly T cells and NK cells through activation of their common CXC chemokine receptor (CXCR)3. They are inactivated upon $\mathrm{NH}_{2}$-terminal cleavage by dipeptidyl peptidase IV/CD26. In the present study, we found that different glycosaminoglycans (GAGs) protect the CXCR3 ligands against proteolytic processing by CD26 without directly affecting the enzymatic activity of CD26. In addition, GAGs were shown to interfere with chemokine-induced CXCR3 signaling. The observation that heparan sulfate did not, and heparin only moderately, altered CXCL10-induced T cell chemotaxis in vitro may be explained by a combination of protection against proteolytic inactivation and altered receptor interaction as observed in calcium assays. No effect of CD26 inhibition was found on CXCL10-induced chemotaxis in vitro. However, treatment of mice with the CD26 inhibitor sitagliptin resulted in an enhanced CXCL10-induced lymphocyte influx into the joint. This study reveals a dual role for GAGs in modulating the biological activity of CXCR3 ligands. GAGs protect the chemokines from proteolytic cleavage but also directly interfere with chemokine-CXCR3 signaling. These data support the hypothesis that both GAGs and CD26 affect the in vivo chemokine function.
\end{abstract}

Keywords: chemokine; glycosaminoglycan; leukocyte migration; posttranslational modification; CXCR3; dipeptidyl peptidase IV; CD26

\section{Introduction}

The family of chemotactic cytokines or chemokines is constituted by a group of low molecular mass proteins that direct specific leukocyte migration in a time- and site-dependent manner in health and disease [1,2]. Chemokines are not only crucial players in basal innate and adaptive immune mechanisms, but are also implicated in a broad range of additional physiological and 
pathophysiological processes ranging from embryonic development and angiogenesis to cancer and autoimmune diseases [3-9]. According to the localization of the conserved $\mathrm{NH}_{2}$-terminal cysteine residues, a sub classification into $\mathrm{CXC}, \mathrm{CC}, \mathrm{CX}_{3} \mathrm{C}$ and $\mathrm{C}$ chemokine subfamilies is respected. CXCL9, CXCL10 and CXCL11 are three CXC chemokines that lack a conserved Glu-Leu-Arg (ELR) amino acid motif and exert their chemotactic activity through interaction with their common $\mathrm{G}$ protein-coupled receptor (GPCR) CXCR3 [10,11]. In order of increasing potency, CXCL9, CXCL10 and CXCL11 activate CXCR3, which is strongly expressed on type-1 helper (Th1) CD4+ T cells, effector CD8+ $\mathrm{T}$ cells and certain innate leukocytes including natural killer (NK) cells [10-12]. In addition to their chemotactic effects, angiostatic properties have been attributed to the CXCR3 ligands [3,5,11,13]. Unique characteristics have been claimed to individual CXCR3 ligands. For example, CXCL11 is the only CXCR3 ligand that also interacts with the atypical chemokine receptor ACKR3 (also known as CXCR7) [14-16]. CXCL9 contains a unique COOH-terminal tail that consists for about $50 \%$ of basic amino acids and differs not only from the two other CXCR3 ligands, but also from almost all chemokines in general (vide infra) [1,17].

As suggested by their alternative names, being monokine induced by interferon (IFN)- $\gamma$ (Mig), IFN- $\gamma$-inducible protein of $10 \mathrm{kDa}$ (IP-10) and IFN- $\gamma$-inducible T cell $\alpha$ chemoattractant (I-TAC), for CXCL9, CXCL10 and CXCL11 respectively, these are inflammatory chemokines with IFN- $\gamma$ as a major inducer. However, the specific expression of individual CXCR3 ligands is differently regulated. Induction of CXCL9 expression is truly IFN- $\gamma$ dependent $[18,19]$, whereas expression of CXCL10 is also induced by a variety of innate stimuli including IFN- $\alpha$ or IFN- $\beta[18,20]$. IFN- $\gamma$ and IFN- $\beta$, but not IFN- $\alpha$, are potent stimulators of CXCL11 expression [21]. Consequently, despite their mutual structural similarities and shared, unique signaling receptor, the CXCR3 ligands show a significant degree of redundancy only in vitro that seems less the case in vivo [10]. During the course of immune responses, the temporal and spatial expression patterns of individual CXCR3 ligands are ligand-specific, with each CXCR3 ligand being regulated by different stimuli and expressed by different cell types $[10,22,23]$. It is therefore believed that in vivo, CXCL9, CXCL10 and CXCL11 each play a unique role in fine-tuning the trafficking of $\mathrm{T}$ cells. Accordingly, in certain inflammatory in vivo models, deficiency for one specific CXCR3 ligand cannot be countervailed by the presence of the two others [24-27]. Additionally, in vivo models exist where full $\mathrm{T}$ cell infiltration requires cooperation between the CXCR3 ligands [28,29]. To add even more complexity to the CXCR3-chemokine loop, apparent ligand antagonism has been described between CXCR3 agonists [30]. Furthermore, one has to keep in mind that most studies in mice concern CXCL10, whereas CXCL9 and certainly CXCL11 have been studied to a lesser extend in vivo. Moreover, it has been reported that a frame shift causing the presence of a stop codon in the CXCL11 gene thus, resulting in deficiency for CXCL11 is present in one of the routinely used mouse strains, i.e., C57BL6 mice [31].

In addition to interaction with chemokine receptors, chemokine-induced leukocyte migration in vivo usually requires also interaction between chemokines and GAGs [32-39]. GAGs, e.g., heparin, heparan sulfate, chondroitin sulfate, keratan sulfate, dermatan sulfate and hyaluronic acid, are present in the extracellular matrix and at the cell surface, usually as part of proteoglycan structures (GAG chains attached to a protein core). Due to their sulfate groups, these heterogeneous polysaccharides are negatively charged and thus attractive interaction partners for the highly basic chemokines [40]. GAGs retain chemokines on endothelial surfaces and prevent washout of chemokines by the blood flow [33]. Of the three main CXCR3 agonists, CXCL9 in particular is an extremely efficient GAG interacting chemokine, due to its highly positively charged long $\mathrm{COOH}$-terminal tail that consists for circa $50 \%$ of basic amino acids. To investigate the function of the COOH-terminal region of CXCL9, our lab previously synthesized several peptides, derived from the COOH-terminal region of CXCL9 [17,41]. Specifically, the longest peptide CXCL9 (74-103) was found to compete with CXCL8 for GAG-binding, thereby preventing CXCL8 from performing its neutrophil-chemotactic function in vivo [17]. CXCL8 is an ELR positive CXC chemokine that activates CXCR1 and CXCR2 and is considered the main human neutrophil-attracting chemokine $[4,42,43]$. In general, binding to GAGs facilitates chemokine retention 
and assists in generation of a chemokine gradient that directs leukocyte migration in vivo [33,44]. Interaction with GAGs also mediates chemokine oligomerization [40] and is thought to play a role in either cis or trans (on endothelial cells) presentation of chemokines to their receptors [45]. In addition, GAGs were shown to serve as a protective factor that prevent the chemokines CXCL12 and CCL11 from proteolysis by specific enzymes [46,47].

Since the identification of chemokines, it has been evidenced that the biological availability and functioning of chemokines is coordinated at multiple levels. These include alternative splicing and mutual synergistic or antagonistic effects between certain chemokines, in addition to the aforementioned interactions with GAGs, specific GPCRs and atypical chemokine receptors [44]. Moreover, a major role for posttranslational processing, e.g., proteolysis, citrullination, glycosylation and nitration, has been recognized in fine-tuning the exact chemokine function and receptor specificity in vitro and in vivo [44,48-51]. An enzyme that has been shown to provoke $\mathrm{NH}_{2}$-terminal processing of various chemokines including CXCL9, CXCL10 and CXCL11 is dipeptidyl peptidase IV or CD26 [50,52,53]. In addition to its enzymatic activity as a serine protease, the multifunctional or "moonlighting" protein CD26 functions as a receptor, costimulator for T cell activation, adhesion molecule and has been associated with apoptosis [54-57]. The membrane-bound enzyme is expressed on cells of different origins, including certain immune cells, whereas soluble proteolytically active CD26 exists in several body fluids such as plasma and seminal fluid. CD26 preferentially removes the two most $\mathrm{NH}_{2}$-terminal amino acids from substrates whose penultimate position is occupied by a (hydroxy) proline or alanine residue. Pro is present at this position in a number of chemokine sequences. The $\mathrm{NH}_{2}$-terminal chemokine domain is responsible for GPCR binding and activation and, consequently, limited proteolysis by CD26 (but also by other enzymes) may have drastic effects on the biological functioning of a chemokine [50-52]. It turned out that the biological effect of CD26-mediated cleavage is highly complex and depends on the chemokine ligand involved. For all three CXCR3 agonists, it was previously demonstrated that processing by CD26 results in drastic loss of receptor signaling and impaired capacity to direct lymphocyte chemotaxis, while leaving the angiostatic properties of these chemokines unaffected [53]. For human CXCL10 and CXCL11, the corresponding CD26-truncated isoforms CXCL10 (3-77) and CXCL11 (3-73) were previously isolated from natural sources, including conditioned medium from MG-63-osteosarcoma cells, fibroblasts and keratinocytes [22,58-61].

In the present study, we wanted to provide new insights in the intriguing role of GAGs in the regulation of the activity of CXCR3 agonists. Specifically, we investigated the effects of GAGs on the CXCR3 chemokine dialog and on CD26-mediated processing of CXCR3 agonists. The relationship between GAGs, CD26, CXCR3 and its chemokine ligands was found to be highly complex and dual: while GAGs dose-dependently preserved CXCL9, CXCL10 and CXCL11 from cleavage by CD26, these negatively charged macromolecules also negatively affected their calcium mobilizing capacities through CXCR3.

\section{Results}

\subsection{Soluble GAGs Protected CXCR3 Ligands against Truncation by Soluble CD26}

GAGs were previously described to protect CXCL12 and CCL11 against proteolytic processing by specific enzymes, either directly or indirectly $[46,47]$. In the present study, we wondered whether this was also true for CD26-mediated truncation of the three most potent CXCR3 chemokine agonists and CD26 substrates CXCL9, CXCL10 and CXCL11. CXCL10, the most intensively studied CXCR3 ligand, was incubated for $2 \mathrm{~h}$ with $12.5 \mathrm{U} / \mathrm{L}$ natural human CD26 and final GAG concentrations up to $26.4 \mu \mathrm{g} / \mathrm{mL}$. We reasoned that, following extraction of truncated and intact CXCL10 from incubation mixtures using $\mathrm{C} 4$ or strong cation exchange purification techniques, the percentage of CD26-mediated CXCL10-processing could be determined with mass spectrometry. However, using this protocol we failed to detect CXCL10 isoforms and we relied on automated $\mathrm{NH}_{2}$-terminal sequencing 
using Edman degradation for quantification of the CD26-mediated conversion of native CXCL10 towards CXCL10(3-77). Dose response experiments were conducted with heparan sulfate and the fixed chain-length heparin variants heparin DP30 and DP8. For all GAGs tested, CXCL10 was dose-dependently protected against proteolytic processing by CD26 (Figure 1). Incubation of CXCL10 with CD26 in the absence of GAG resulted in almost complete truncation of intact CXCL10 by two amino acids towards CXCL10 (3-77). At GAG concentrations up to $2.64 \mu \mathrm{g} / \mathrm{mL}$, almost all CXCL10 was processed, whereas GAG concentrations of $8.8 \mu \mathrm{g} / \mathrm{mL}$ offered the chemokine almost full protection against proteolytic processing by the serine protease.

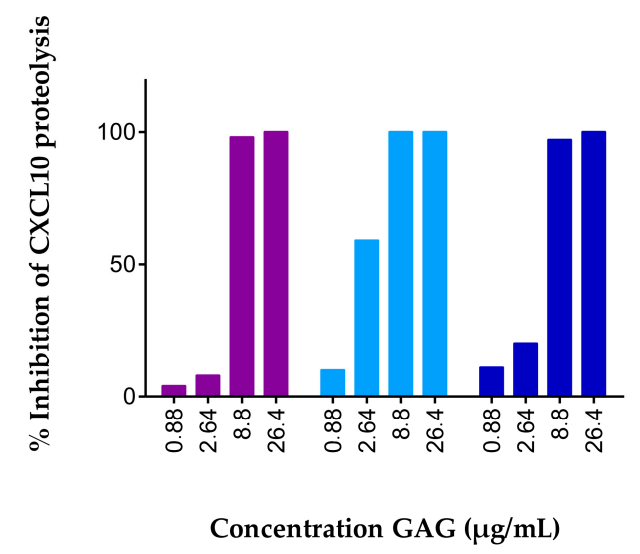

Figure 1. GAGs dose-dependently protect CXCL10 from cleavage by CD26. Recombinant human CXCL10 $(20 \mu \mathrm{g} / \mathrm{mL})$ was incubated with $12.5 \mathrm{U} / \mathrm{L}$ natural human CD26 and 0.88 to $26.4 \mu \mathrm{g} / \mathrm{mL}$ heparan sulfate (violet, ๑), heparin DP30 (blue, ๑), or heparin DP8 (deep blue, ๑)), in $50 \mathrm{mM}$ Tris buffer supplemented with 1 mM EDTA (pH 7.5). Incubation of CXCL10 with CD26 in the absence of GAG was used as a control. Reactions were terminated after $2 \mathrm{~h}$ by acidification to $0.08 \%(v / v)$ trifluoroacetic acid (TFA). The ratio of truncated CXCL10 (3-77) over corresponding intact chemokine was determined with automated $\mathrm{NH}_{2}$-sequencing. Results are represented as percentages of GAG-mediated inhibition of proteolysis of CXCL10 by CD26.

Inspired by these drastic effects of GAGs on CD26-mediated truncation of CXCL10, we investigated the effects of GAGs on CD26-mediated processing of the two other IFN- $\gamma$-inducible CXCR3 chemokine agonists, i.e., CXCL9 and CXCL11. Accordingly, we optimized the desalting process after the CD26 incubation and found that chemokines could be detected and quantified by mass spectrometry after pre-purification on $\mathrm{C} 18$ pipette tips if the GAG concentrations did not exceed $8.8 \mu \mathrm{g} / \mathrm{mL}$. The three main CXCR3 agonists were incubated with CD26 in the absence or presence of 8.8, 2.64 or $0.88 \mu \mathrm{g} / \mathrm{mL}$ heparan sulfate, heparin, chondroitin sulfate A or chondroitin sulfate $\mathrm{C}$. All these GAGs had a relative molecular mass $\left(\mathrm{M}_{\mathrm{r}}\right)$ of $40 \mathrm{kDa}$ (data not shown). After an incubation period of $2 \mathrm{~h}, \mathrm{CD} 26$ activity was stopped through acidification with TFA. Samples were desalted with C18 tips and subjected to mass spectrometry. Without GAGs, almost all CXCL10 and CXCL11 was cleaved by CD26 to CXCL10 (3-77) and CXCL11(3-73), respectively. In contrast, CXCL9 was processed by the enzyme for only about $20 \%$ (data not shown). These findings were in line with previous studies which demonstrated that CXCL10, and especially CXCL11, are highly efficient CD26 substrates, whereas the half-life of CXCL9 upon incubation with the enzyme is remarkably longer [53,62]. The presence of heparin, heparan sulfate, chondroitin sulfate $\mathrm{A}$ or chondroitin sulfate $\mathrm{C}$ in the incubation mixture protected the three IFN-induced CXCR3 ligands dose-dependently from truncation by CD26 (Figure 2, Figures S1-S3). At $8.8 \mu \mathrm{g} / \mathrm{mL}$ heparin, heparan sulfate, chondroitin sulfate A and C completely prevented processing of CXCL9 and CXCL10 by CD26. A comparable protective effect was obtained with heparan sulfate and chondroitin sulfate $C$, whereas heparin and chondroitin sulfate A were less efficient in protecting CXCL11 from proteolytic truncation by CD26. Thus, the obtained results indicated a dose-dependent, GAG-mediated chemokine protection against processing by CD26 for 
all GAGs tested. However, minor differences in efficiency were detected between the different GAGs although they all had a comparable molecular mass.

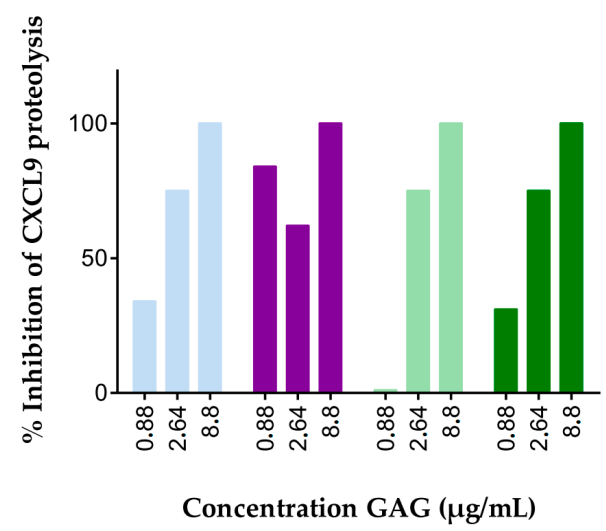

(A)

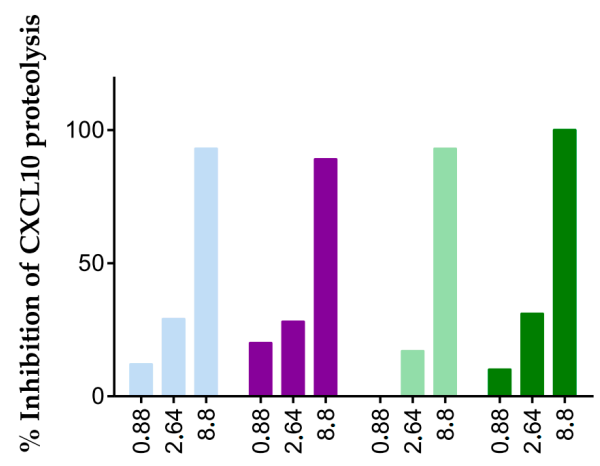

Concentration GAG $(\mu \mathrm{g} / \mathrm{mL})$

(B)

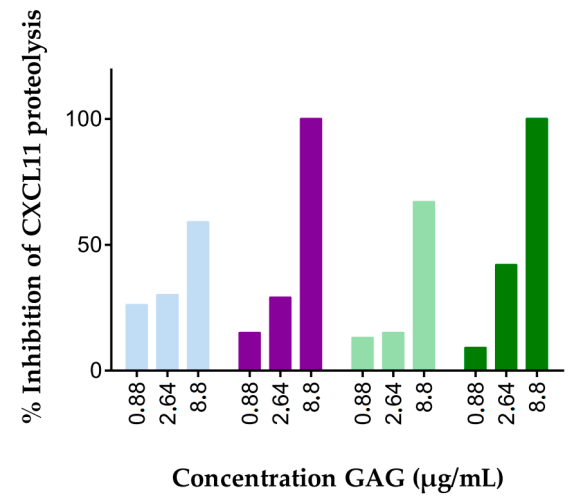

(C)

Figure 2. GAGs dose-dependently protect IFN- $\gamma$-inducible CXCR3 ligands from cleavage by CD26. Recombinant human: CXCL9 (A); CXCL10 (B) or CXCL11(C) $(20 \mu \mathrm{g} / \mathrm{mL})$ was incubated with $12.5 \mathrm{U} / \mathrm{L}$ natural human CD26 and 0.88 to $8.8 \mu \mathrm{g} / \mathrm{mL}$ heparan sulfate (violet, $\bullet$ ), heparin (light blue, $\odot$ ), chondroitin sulfate A (light green, $)$ ) or chondroitin sulfate C (green, ๑) in $50 \mathrm{mM}$ Tris buffer supplemented with $1 \mathrm{mM}$ EDTA $(\mathrm{pH} 7,5)$. Reactions were terminated after $2 \mathrm{~h}$ by acidification to $0.08 \%(v / v)$ TFA. The ratio of truncated CXCL9(3-103), CXCL10(3-77) or CXCL11(3-73) over corresponding intact chemokines was determined after $\mathrm{C} 18$ purification and mass spectrometry. Results are represented as percentages of GAG-mediated inhibition of proteolysis of CXCL10 by CD26. 


\subsection{GAGs Did Not Inhibit the Enzymatic Activity of Soluble CD26 Directly}

The exact enzymatic activity of the purified natural human CD26 sample was determined to be $4.6 \pm 0.6 \mathrm{U} / \mathrm{L}$ (mean $\pm \mathrm{SEM}, n=3$ ) using a chromogenic assay with Gly-Pro-p-nitroanilide (Gly-Pro-pNA) as the substrate. No pNA release was observed upon incubation of the substrate with the highest concentration of heparin DP30 in the absence of CD26. To investigate a direct effect of GAGs on the activity of the enzyme, the release of pNA was detected when Gly-Pro-pNA and CD26 were incubated in the absence or presence of 10 or $100 \mu \mathrm{g} / \mathrm{mL}$ heparin DP30. The CD26 activities in conditions with and without GAG were highly similar (Table 1). Thus, no evidence was found for GAGs to inhibit the proteolytic activity of CD26 directly, which was in line with a former study that reported that heparan sulfate did not inhibit the enzymatic activity of CD26 [46].

Table 1. Effect of heparin on the proteolytic activity of CD26.

\begin{tabular}{cc}
\hline Concentration Heparin DP30 $(\mu \mathrm{g} / \mathrm{mL})$ & CD26 Activity $(\mathrm{U} / \mathrm{L})$ \\
\hline 0 & 4.6 \\
10 & 4.19 \\
100 & 4.35 \\
\hline
\end{tabular}

\subsection{GAGs Interfered with Chemokine Signaling through CXCR3}

Chemokine-induced CXCR3-signaling is associated with the release of intracellular calcium from the endoplasmic reticulum. Consequently, we reasoned that measuring the $\left[\mathrm{Ca}^{2+}\right]_{\mathrm{i}}$ after stimulation of cells with CXCL9, CXCL10 or CXCL11 with or without GAGs, would provide us with new insights on the effect of GAGs on the chemokine-induced G protein-dependent signaling through CXCR3. To this end, Chinese Hamster Ovarian (CHO) cells, stably transfected with CXCR3A and loaded with the calcium-binding fluorescent dye Fura-2, were stimulated with final concentrations of $3 \mathrm{ng} / \mathrm{mL}$ to $1 \mu \mathrm{g} / \mathrm{mL}$ CXCL9, CXCL10 or CXCL11. The corresponding chemokine-induced calcium responses were calculated using the Grynkiewicz equation. For CXCL10 and CXCL11, a concentration of $3 \mathrm{ng} / \mathrm{mL}$ resulted in an increase of the $\left[\mathrm{Ca}^{2+}\right]_{\mathrm{i}}$ with $106.8 \mathrm{nM}(n=39)$ and $304.5 \mathrm{nM}(n=18)$, respectively, and $3 \mathrm{ng} / \mathrm{mL}$ CXCL10 or CXCL11 was selected for further experiments in combination with GAGs. Cells were treated with CXCL10 or CXCL11 with or without $0.04 \mu \mathrm{g} / \mathrm{mL}, 2 \mu \mathrm{g} / \mathrm{mL}$ or $10 \mu \mathrm{g} / \mathrm{mL}$ GAG. Representative experiments are shown in Figure 3. The observed calcium responses were calculated as percentages of the corresponding reference values in the absence of GAGs. A dose-dependent negative correlation was found between the GAG concentration and the ability of CXCL10 and CXCL11 to evoke an intracellular calcium release through CXCR3 (Figure 4A,B). Heparin molecules with different length were tested in combination with CXCL10 and the longer heparin molecules were more potent inhibitors of the calcium response compared to the shorter DP8 form. For the less potent CXCL9, a concentration of $1 \mu \mathrm{g} / \mathrm{mL}$ was selected, resulting in an increase of the $\left[\mathrm{Ca}^{2+}\right]_{\mathrm{i}}$ with $598.1 \mathrm{nM}(n=4)$. Heparan sulfate also dose dependently inhibited the calcium response induced by this weaker CXCR3 ligand (Figure 4C). It remains to be elucidated whether the effect of GAGs on calcium signaling is due to direct binding of GAGs to chemokines, CXCR3 or both. In addition, it cannot be excluded that GAGs directly interfere with intracellular signaling. However, as expected, GAGs did not induce an increase of the $\left[\mathrm{Ca}^{2+}\right]_{i}$ in the absence of chemokine (data not shown). 


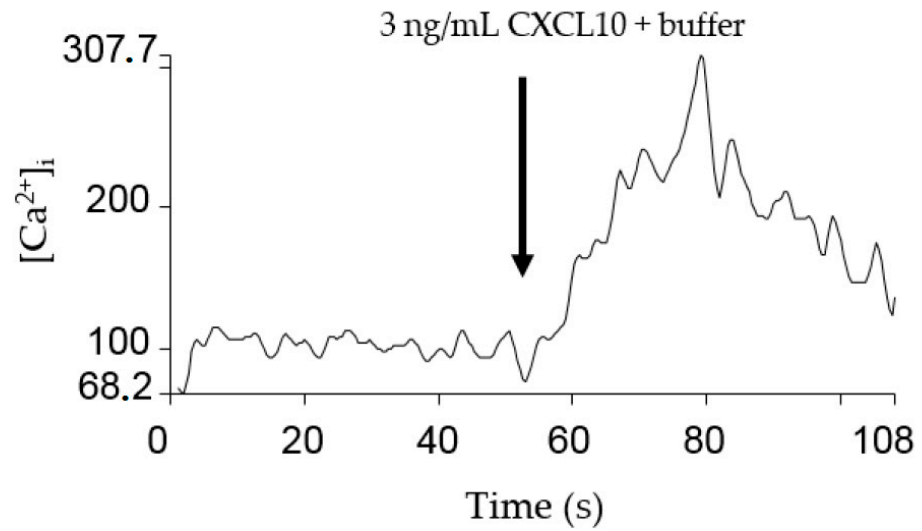

(A)

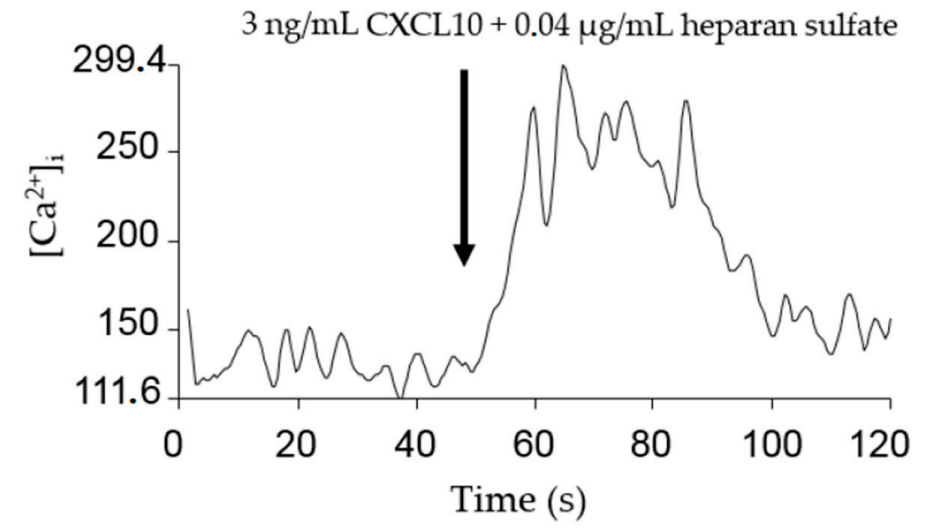

(B)

$3 \mathrm{ng} / \mathrm{mLCXCL10}+2 \mu \mathrm{g} / \mathrm{mL}$ heparan sulfate

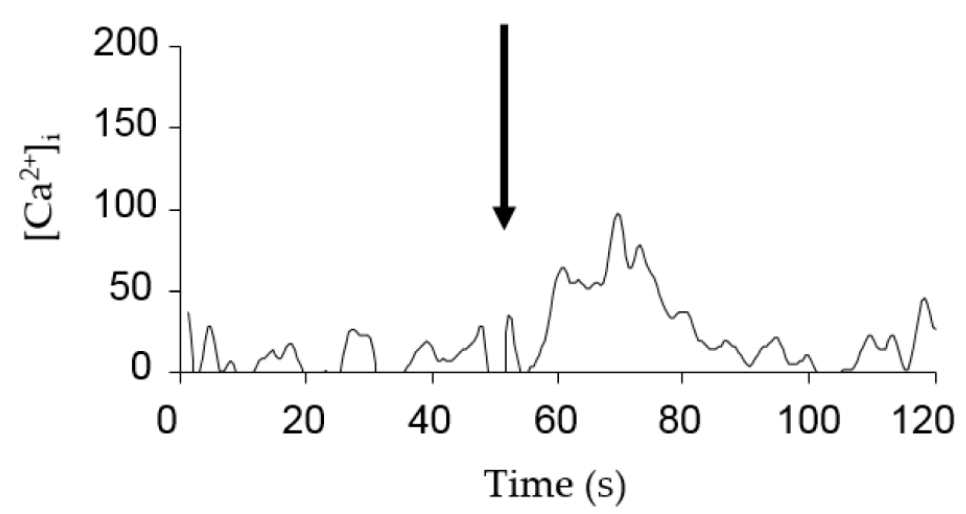

(C)

Figure 3. Cont. 


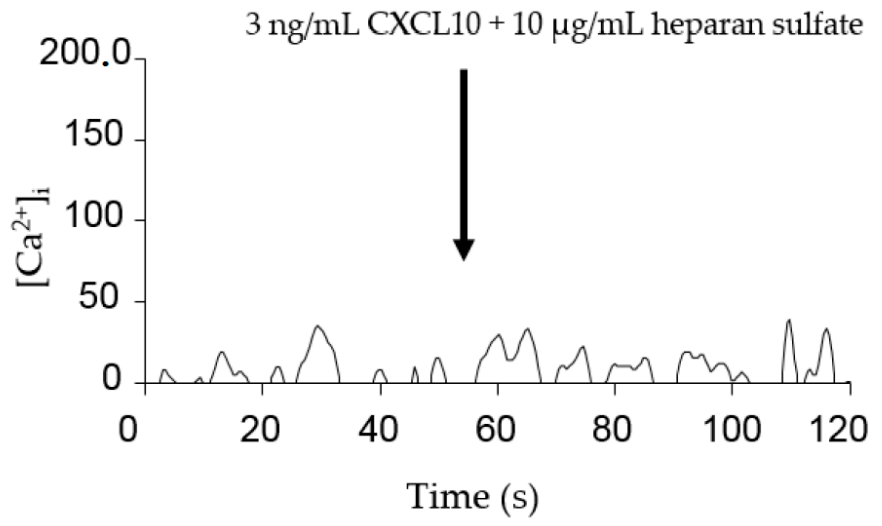

(D)

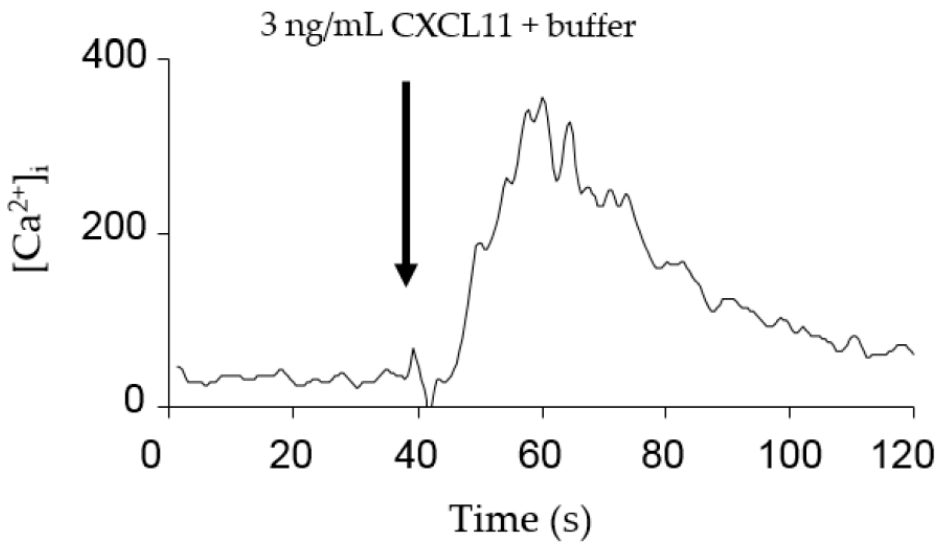

(E)

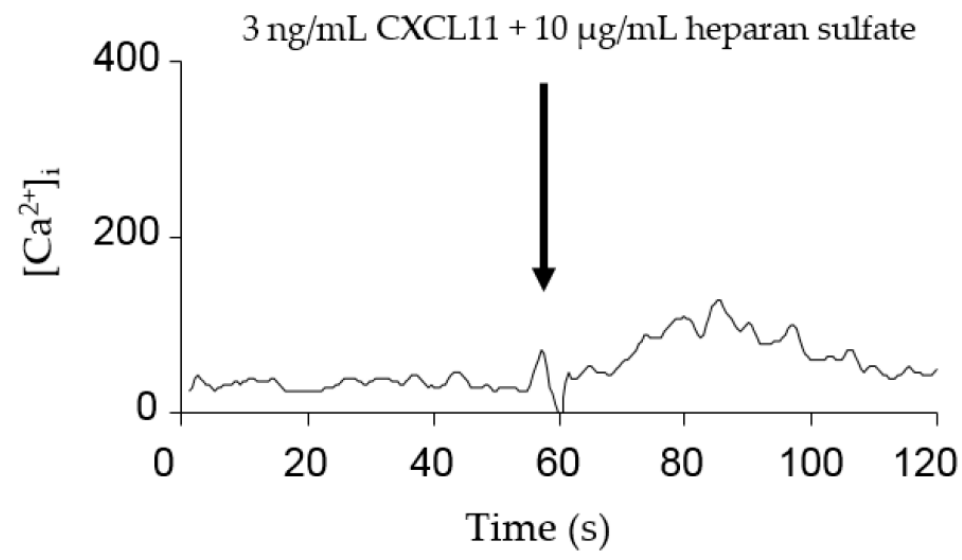

(F)

Figure 3. Cont. 


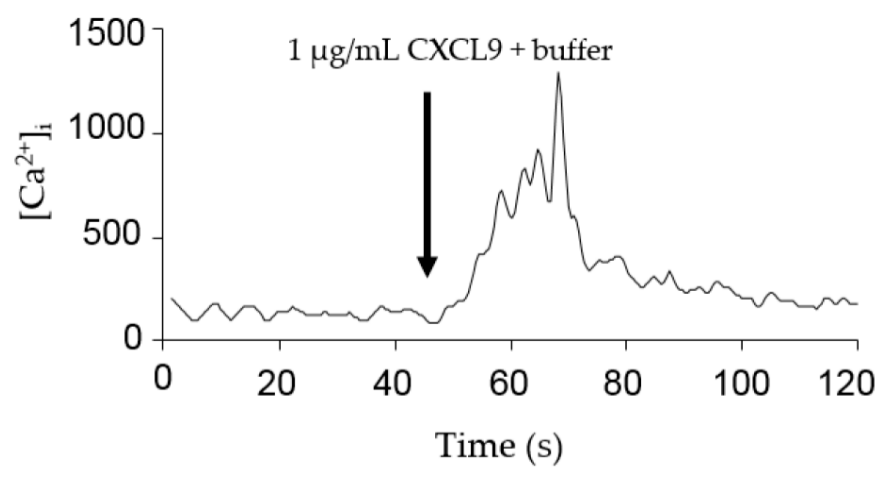

(G)

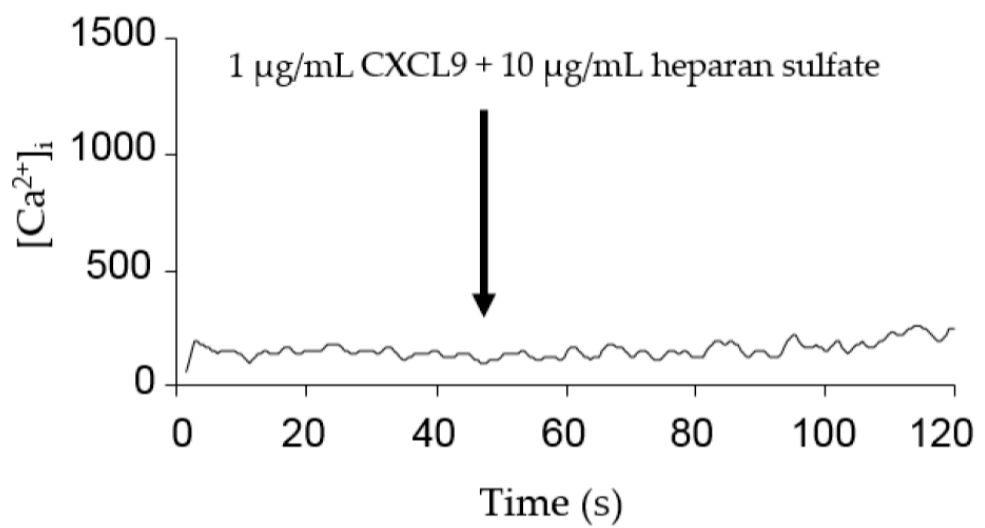

(H)

Figure 3. Effect of heparan sulfate on chemokine-induced calcium signaling through CXCR3. CHO/CXCR3A cells were stimulated with $3 \mathrm{ng} / \mathrm{mL}$ : CXCL10 (A-D); or CXCL11 (E,F); or $1 \mu \mathrm{g} / \mathrm{mL}$ CXCL9 $(G, H)$ in the presence or absence of GAG. $\left[\mathrm{Ca}^{2+}\right]_{i}$ concentrations were calculated using the equation of Grynkiewicz et al. Figures show representative experiments in which cells were simultaneously stimulated with chemokine and buffer (A,E,G); or $0.04 \mu \mathrm{g} / \mathrm{mL}(\mathbf{B}) ; 2 \mu \mathrm{g} / \mathrm{mL}$ (C); or $10 \mu \mathrm{g} / \mathrm{mL}(\mathbf{D}, \mathbf{F}, \mathbf{H})$ heparan sulfate.

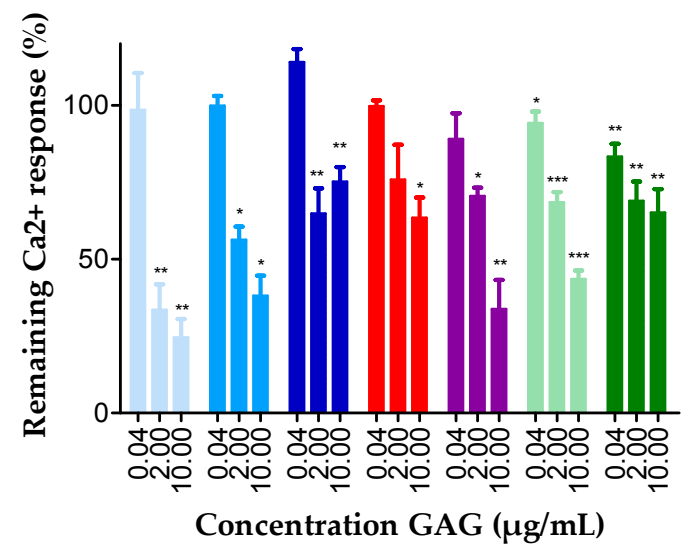

(A)

Figure 4. Cont. 


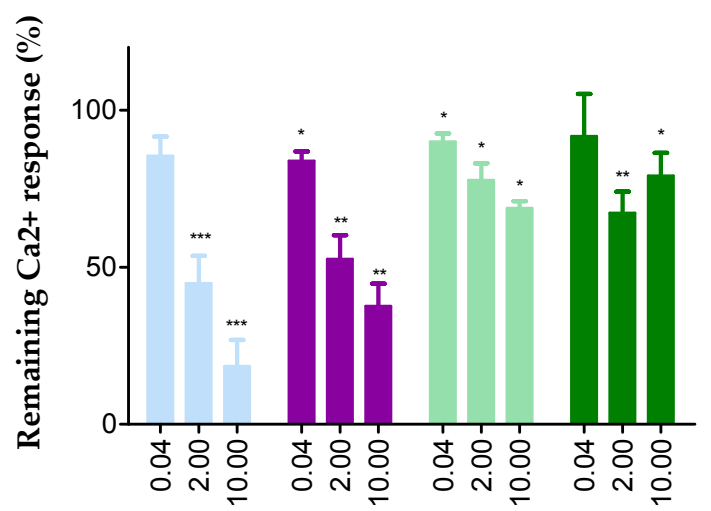

Concentration GAG $(\mu \mathrm{g} / \mathrm{mL})$

(B)

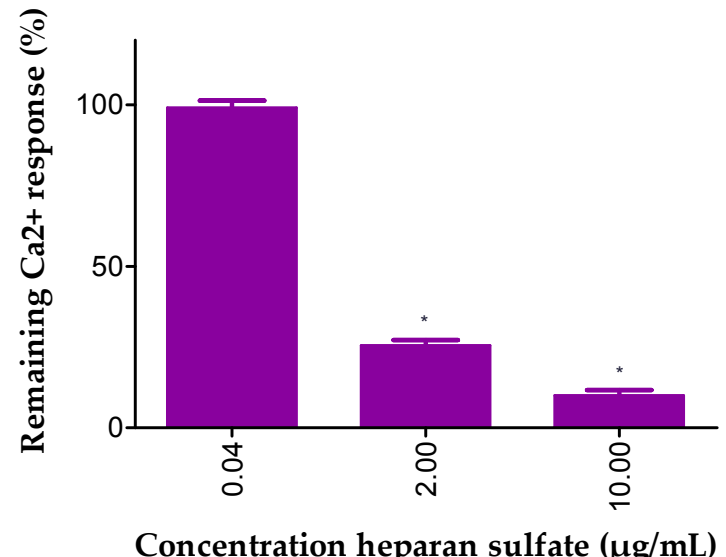

(C)

Figure 4. GAGs interfere with chemokine signaling through CXCR3. CHO/CXCR3A cells were stimulated with $3 \mathrm{ng} / \mathrm{mL}$ : CXCL10 (A); or CXCL11 (B); or $1 \mu \mathrm{g} / \mathrm{mL}$ CXCL9 (C) in the presence or absence of heparan sulfate (violet, ๑), heparin (light blue, ๑), heparin DP30 (blue, ๑), heparin DP8 (deep blue, ๑), dermatan sulfate (red, ๑), chondroitin sulfate A (light green, $\bullet$ ) or chondroitin sulfate $\mathrm{C}$ (green, $\odot$ ). $\left[\mathrm{Ca}^{2+}\right]_{\mathrm{i}}$ concentrations were calculated using the equation of Grynkiewicz et al. Mann-Whitney U-tests were performed to statistically compare $\left[\mathrm{Ca}^{2+}\right]_{i}$ concentrations obtained after stimulation with CXCL9, CXCL10 or CXCL11 plus GAG, with $\left[\mathrm{Ca}^{2+}\right]_{\mathrm{i}}$ concentrations that resulted from stimulation with, respectively, CXCL9, CXCL10 or CXCL11 only $\left({ }^{*}=p<0.05 ;{ }^{* *}=p<0.01\right.$; $* * *=p<0.001)$. Results are represented as mean percentages $( \pm \mathrm{SEM})$ compared to conditions in which cells were stimulated with CXCL9, CXCL10 or CXCL11 without GAG. Percentages are means of 3-8 independent experiments.

\subsection{Effect of Soluble GAGs on CXCL10-Mediated CD26-Positive T Cell Chemotaxis In Vitro}

Activated T cells express membrane-bound CD26. Thus, we wondered whether the observed GAG-mediated protection of CXCL10 against inactivation by CD26 was reflected in an increased CXCL10-induced T cell chemotaxis. To this end, we first confirmed CD26 expression and activity on cultured $\mathrm{T}$ cells. Flow cytometry was performed and revealed that, as expected, the majority of cultured cells expressed CD26 in addition to CD3 and CXCR3 (data not shown). Different cell concentrations were incubated with the CD26 substrate Gly-Pro-pNA and the enzymatic activity was determined. As expected, an increased enzymatic activity was found with increasing concentrations of $\mathrm{T}$ cells (data not shown). Purified soluble natural seminal fluid-derived CD26 was used as a positive control.

Subsequently, in vitro Boyden chamber assays were conducted to evaluate the effects of GAGs on CXCL10-mediated chemotaxis of T cells. We investigated the migratory response of T cells towards 3 
to $300 \mathrm{ng} / \mathrm{mL}$ CXCL10 with or without 0.04 or $4 \mu \mathrm{g} / \mathrm{mL}$ soluble heparin or heparan sulfate (Figure 5). Chemotactic indices were calculated by dividing the number of migrated cells to chemokine by the number of cells that migrated in response to buffer. As expected, a dose-dependent CXCL10-mediated $\mathrm{T}$ cell chemotaxis was observed with $10 \mathrm{ng} / \mathrm{mL}$ to $300 \mathrm{ng} / \mathrm{mL}$ CXCL10. In contrast to our expectations, presence of soluble heparan sulfate did not significantly affect CXCL10-induced T cell chemotaxis in vitro (Figure $5 \mathrm{~A})$. Heparin $(4 \mu \mathrm{g} / \mathrm{mL})$ significantly inhibited T cell chemotaxis to $300 \mathrm{ng} / \mathrm{mL}$ CXCL10 and a trend towards reduced chemotaxis was found for other CXCL10 concentrations (Figure 5B). It remains to be determined whether the lack of inhibition with heparan sulfate was due to in vitro counteraction between the two observed GAG-mediated phenomena, i.e. heparan sulfate-mediated protection of CXCL10 against processing by CD26 on the one hand, and the negative effect of heparan sulfate on the CXCR3-CXCL10 dialog on the other hand.

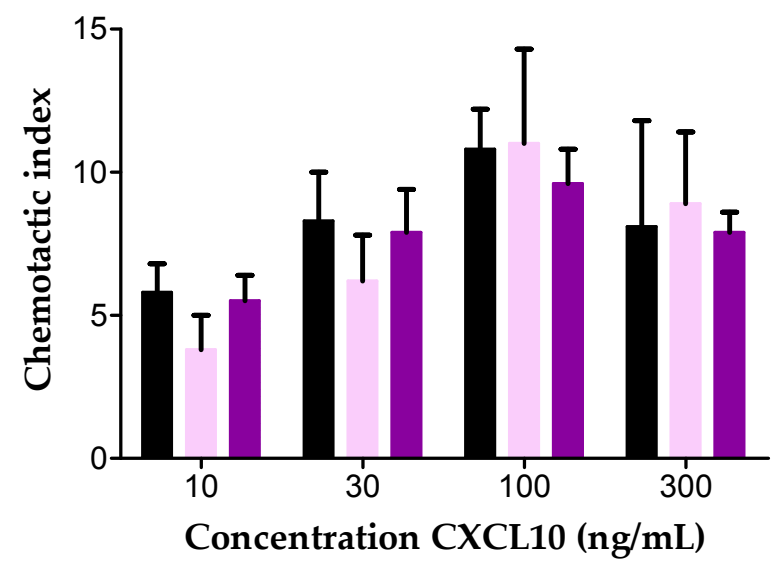

(A)

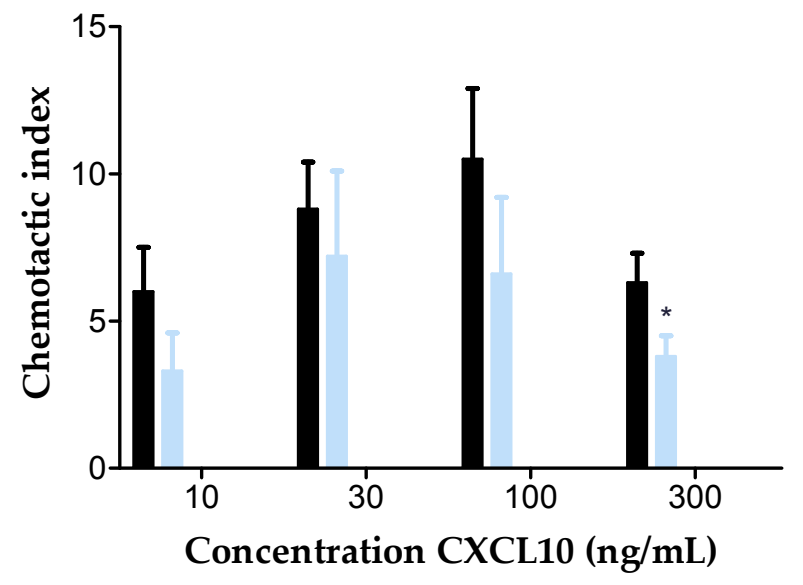

(B)

Figure 5. Effect of GAGs on CXCL10-induced T cell chemotaxis in vitro. The effects of: $0.04 \mu \mathrm{g} / \mathrm{mL}$ (light violet, ○), or $4 \mu \mathrm{g} / \mathrm{mL}$ (violet, ๑) soluble heparan sulfate (A); or $4 \mu \mathrm{g} / \mathrm{mL}$ (light blue, ○) heparin (B) on the in vitro migratory response of PHA-activated T cells towards10-300 ng/mL CXCL10 was investigated using the 48 well Boyden chamber chemotaxis assay. Values represent the mean chemotactic index $( \pm$ SEM) $(n=7)$. Statistical analysis was performed using the Mann-Whitney U test. $*=p<0.05$; compared to stimulation with CXCL10 without GAG (black, $\bullet$ ).

\subsection{Inhibition of Membrane-Bound CD26 Did Not Affect CXCL10-Mediated T Cell Chemotaxis In Vitro}

To directly investigate the effects of specific inhibition of CD26-mediated cleavage of CXCL10 on CXCL10-directed $\mathrm{T}$ cell migration, chemotaxis assays were performed in the presence of the specific CD26 inhibitor sitagliptin. We first conducted a CD26 activity test with T cells that were treated with 0 
to $2 \mathrm{mM}$ sitagliptin and demonstrated that sitagliptin dose-dependently decreased the CD26 activity of cultured T cells (Figure 6). A concentration of $200 \mu \mathrm{M}$ was selected for use in in vitro chemotaxis experiments. No significantly increased CXCL10-mediated T cell chemotaxis was observed when cells were treated with sitagliptin, which was in contrast with our expectations and with former in vivo studies [52,63] (Figure 7). However, in vivo, soluble CD26 is present on capillary endothelial cells and in body fluids including plasma, whereas, in our in vitro chemotaxis experiments, CXCL10 was only confronted with membrane-bound CD26 on the T cells. Therefore, it could be speculated that CXCL10 in in vitro assays was already bound to CXCR3 prior to potential truncation by CD26. Additionally, it cannot be excluded that, under the usedin vitro conditions, the amount of membrane-bound CD26 was too low to be able to detect a significant influence of its inhibition by sitagliptin.

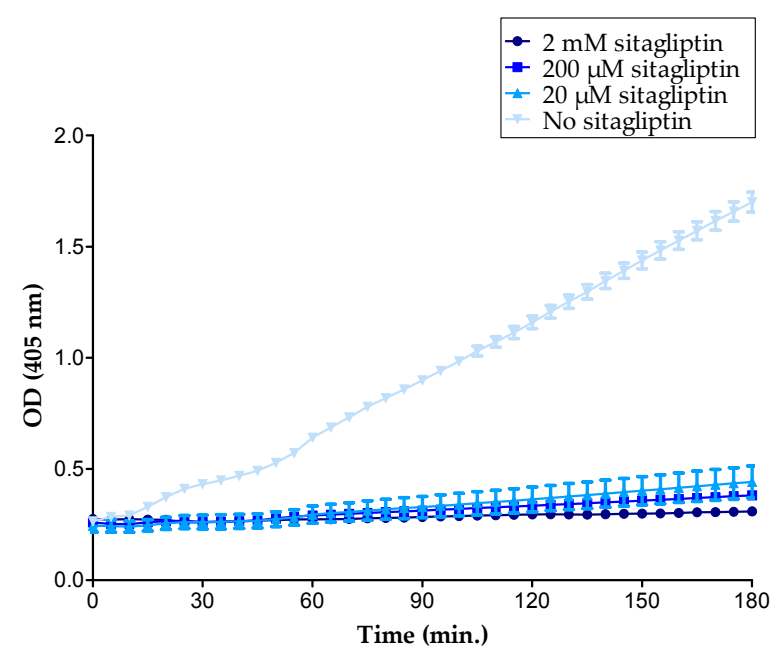

Figure 6. Sitagliptin inhibits CD26 proteolytic activity on T cells. In total, $3 \times 10^{6}$ cells per mL were incubated with $500 \mu \mathrm{M}$ Gly-Pro-pNA with or without $20 \mu \mathrm{M}$ to $2 \mathrm{mM}$ sitagliptin in $75 \mathrm{mM}$ Tris-HCl buffer ( $\mathrm{pH}$ 8.3). OD values were measured at $405 \mathrm{~nm}$ and plotted in function of time to construct CD26 activity curves. The figure shows mean values $( \pm S E M)$ of a representative experiment.

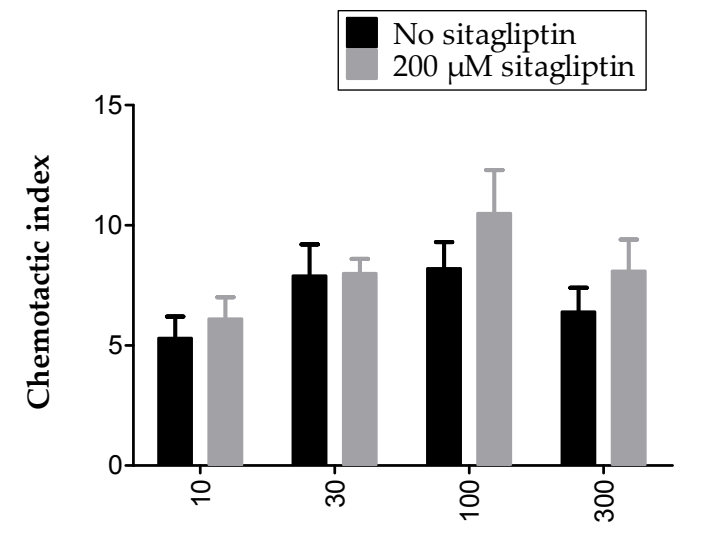

Concentration CXCL10 (ng/mL)

Figure 7. Sitagliptin did not affect CXCL10-induced T cell chemotaxis in vitro. The effects of treatment with $200 \mu \mathrm{M}$ sitagliptin on the in vitro migratory response of PHA-activated T cells towards $10-300 \mathrm{ng} / \mathrm{mL}$ CXCL10 was investigated using the 48 well Boyden chamber chemotaxis assay. Values represent the mean chemotactic index $( \pm$ SEM) $(n=6)$. Statistical analysis was performed using the Mann-Whitney U test. 


\subsection{Inhibition of CD26 Significantly Increased CXCL10-Induced Lymphocyte Influx into the Joint In Vivo}

Chemokine injection into the tibiofemoral articulation was used as an experimental model to study the effect of specific CD26 inhibition in vivo, since this model has the advantage of very low basal leukocyte counts upon vehicle injection (Figure 8). Moreover, CXCL10 is typically a chemokine found in high concentrations in synovial fluids from inflammatory joints of patients with septic, rheumatoid or psoriatic arthritis [22,23]. To investigate the in vivo effect of CD26 inhibition on CXCL10-induced lymphocyte recruitment into the joint, CXCL10 was injected into the tibiofemoral articulation of sitagliptin-treated and untreated mice.

No lymphocyte infiltration was seen in mice that did receive vehicle injection in the joint. Injection of CXCL10 resulted in a lymphocyte recruitment in both untreated and sitagliptin treated mice (Figure 8). However, the number of lymphocytes in joints of mice that had received sitagliptin was significantly higher than the lymphocyte counts in mice that were not treated with the CD26 inhibitor. These results provide direct in vivo evidence that CD26 inhibition protects CXCL10 against cleavage, which is reflected into an enhanced lymphocyte extravasation into the joint. Moreover, these findings are in line with previous studies that reported that sitagliptin treatment in mice is translated into increased CXCL10-mediated lymphocyte infiltration into tumor tissue [63] and increased lymphocyte recruitment to intraperitoneally injected CXCL10 [52].

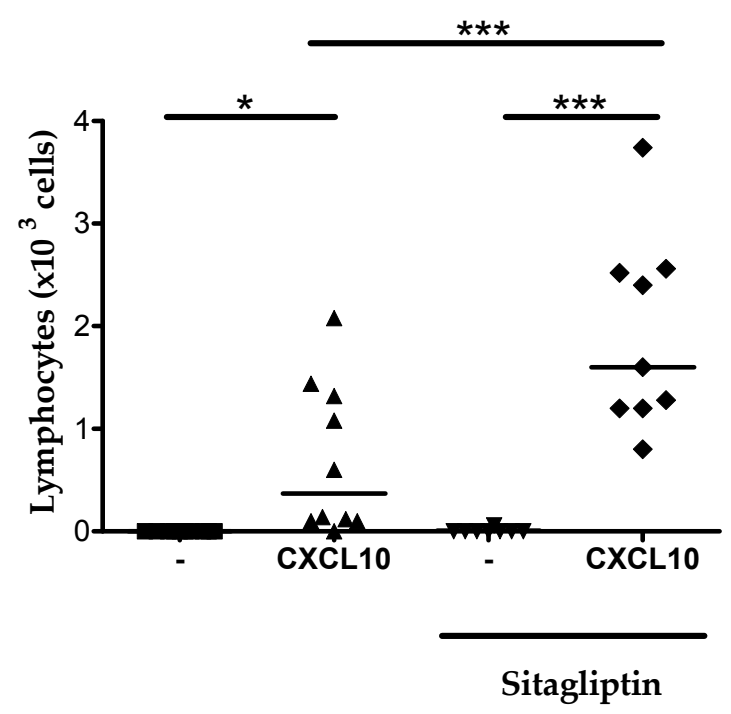

Figure 8. Sitagliptin-treatment of mice enhances CXCL10-mediated lymphocyte extravasation into the joint. The effect of CD26 inhibition on CXCL10-induced lymphocyte extravasation was determined in vivo. Vehicle or CXCL10 were injected into the tibiofemoral articulation of sitagliptin-treated C57BL/ 6 mice. Total leukocyte numbers migrated into the joint were determined $3 \mathrm{~h}$ post injection. Percentages of lymphocytes were differentially counted on May-Grünwald-Giemsa stained cytospins and were used to calculate total lymphocyte numbers. Each symbol represents an individual mouse $(n \geq 8)$. Horizontal lines indicate the median number of lymphocytes for each treatment group. Statistical analysis was performed using the Mann-Whitney $U$ test. ${ }^{*} p<0.05,{ }^{* * *} p<0.001$.

\section{Discussion}

Binding of chemokines to GAGs is essential to generate chemotactic gradients in vivo [32-39]. Moreover, it has been evidenced that the impact of the interaction with GAGs extends beyond the mere facilitation of chemokine retention on the endothelium, thereby locally concentrating chemokines on the cell surface [44]. Interaction with GAGs was found to mediate chemokine oligomerization and to provoke protection against proteolysis by specific enzymes. For example, CXCL12 was protected by heparan sulfate and heparin oligosaccharides against cleavage by CD26 [46]. CXCL12 or stromal derived factor 1 (SDF-1) is an ELR negative CXC chemokine that induces chemotaxis of lymphocytes 
and CD34 positive progenitor cells through activation of CXCR4. Via interaction with the same receptor, CXCL12 holds anti-HIV properties [64-67]. The chemotactic, CXCR4 dependent signaling and antiviral effects of CXCL12 are lost upon truncation by CD26 [68,69]. In the present study, we demonstrated that GAGs also protect CXCL9, CXCL10 and CXCL11 against proteolytic processing by CD26. Of note, the study by Sadir et al. [46] relied on colon carcinoma cells as source of CD26 activity whereas in our experiments, natural soluble CD26, isolated from human seminal fluid and purified to homogeneity, was used.

Another study reported that murine CCL11, also named eotaxin, is no longer processed by plasmin, elastase and cathepsin $G$ upon interaction with immobilized heparin [47]. Here, the authors found that heparin directly inhibits the enzymatic activity of elastase and cathepsin $G$ but not plasmin. In the present study, no evidence was found for GAGs to directly block the enzymatic activity of CD26. These results are in line with the aforementioned CXCL12 study were the investigators showed that the enzymatic activity of CD26 was not blocked by heparan sulfate [46]. We therefore suppose that the observed role for GAGs in offering the CXCR3 ligands protection against processing by CD26 is rooted at the level of chemokine-GAG interactions, thereby providing steric hindrance at the level of the $\mathrm{NH}_{2}$-terminal domain of the chemokine. For CXCL12 it was shown that the protection of the $\mathrm{NH}_{2}$-terminus depends on GAG-induced oligomerization of the chemokine rather than straight interaction with the $\mathrm{NH}_{2}$-terminal Lys residue [70]. It remains to be elucidated whether the protective effect of GAG interaction on CXCR3 ligands is a result of GAG-mediated chemokine oligomerization or direct steric hindrance at their $\mathrm{NH}_{2}$-terminus. Nota bene, GAG-mediated chemokine oligomerization seems an intriguing mechanism on its own, but the molecular details remain largely unknown. Indeed, although chemokine monomers seem responsible for GPCR activation, GAG-mediated induction or stabilization of chemokine oligomers is a prerequisite for the in vivo activity of certain chemokines including CXCL10 [33,36,71]. In return, oligomerization may enhance chemokine affinity for GAGs, which is also dependent on specific GAG density [72]. Oligomeric forms were described for CXCL9 and CXCL10 at physiological concentrations, whereas the oligomeric state of CXCL11 is less understood [36,73-75]. However, a key role for oligomerization of several chemokines including CXCL11 was recently demonstrated in facilitating reorganization and bridging of GAG chains, thereby conferring another level of complexity to the chemokine-GAG dialog [72].

The CXCR3 agonists, specifically CXCL9, CXCL10 and CXCL11, all contain a proline residue in the penultimate $\mathrm{NH}_{2}$-terminal sequence and are biologically relevant CD26 substrates. Upon incubation of $5 \mu \mathrm{M}$ chemokine with a normal plasma concentration of $25 \mathrm{U} / \mathrm{L}$ CD26, the half-lives of CXCL10 and CXCL11 were previously demonstrated to be, respectively, not more than 4 and $2 \mathrm{~min}$, whereas CD26-mediated cleavage of CXCL9 was found to occur less efficiently (half-life of 24 min under the same experimental conditions) [62]. Following cleavage by CD26, the three CXCR3 agonists are biologically inactive in chemotaxis and CXCR3-dependent signaling assays and show a decreased effect on T cells. Moreover, CXCL10(3-77) and CXCL11(3-73) act as CXCR3 antagonists [53]. The CD26-truncated isoform CXCL10(3-77) was originally isolated from natural sources including conditioned medium from MG-63 osteosarcoma cells and fibroblasts [22,58]. Studies with CXCL10 ${ }^{-/-}$ mice established a crucial role for CXCL10 in the generation of effector T cells and in T cell trafficking in general [76]. This important physiological role of CXCL10, but also CXCL9 and CXCL11, combined with the fact that CXCL9(3-103), CXCL10(3-77) and CXCL11(3-73) are inactive, supports the idea that CD26-mediated proteolysis of the CXCR3 agonists may have major biological consequences. Results of multiple studies provided evidence in favor of this hypothesis. In mice, truncation of CXCL10 by CD26 reduces the infiltration of T cells into tumor tissue [63] and towards intraperitoneally injected CXCL10 [52] and consequently impairs the natural antitumor immunity Administration of the CD26 inhibitor sitagliptin significantly improved the natural antitumor immunity of these mice and their response to existing immunotherapies. In human, the biologically inactive isoform CXCL10(3-77) was found in plasma from patients that suffer from chronical hepatitis $C$ viral infections [77]. Moreover, two prospective studies recently confirmed the CD26-mediated processing of human CXCL10 in vivo, and 
provided direct evidence in favor of CD26 inhibition to preserve intact CXCL10 [78]. Although human CXCL11 activates CXCR3 with higher potency and is even more efficiently processed by CD26 than CXCL10, the CD26-CXCL11 axis has been studied to a lesser extend in an in vivo context. It is likely to assume that this can be at least partially explained by the fact that murine CXCL11, in contrast to its human counterpart, contains a methionine residue in its penultimate position and is therefore no substrate for CD26. Interestingly, natural human CXCL11(3-73) was previously isolated from IFN- $\gamma$ stimulated keratinocytes [59-61]. In addition, murine CXCL9 is no CD26 substrate due to the leucine residue that occupies the penultimate position in its $\mathrm{NH}_{2}$-terminal amino acid sequence. However, in view of the efficient cleavage of all three human CXCR3 agonists, our observed GAG-mediated protection may be highly significant depending on the local conditions in specific human tissues. Indeed injection of CXCL10 in joints still induces limited lymphocyte migration (Figure 8), whereas injection of CXCL10 in the peritoneum did not attract lymphocytes [52].

In the present study, we found that soluble GAGs significantly reduce the calcium mobilizing capacities of CXCL9, CXCL10 and CXCL11 through CXCR3. Given the general idea that the $\mathrm{NH}_{2}$-terminal chemokine domain facilitates receptor interaction whereas the $\mathrm{COOH}$-region is considered the major GAG-binding domain, this observation may seem somewhat unexpected. However, it was previously suggested that both interaction domains are not necessarily restricted to, respectively, the $\mathrm{NH}_{2}$ - and $\mathrm{COOH}$-terminus. The relevance of this hypothesis for CXCL10 for example, is supported by the fact that mutation of amino acids 20 to 24, 46 and 47 impairs both the heparin affinity of the chemokine and its binding and signalization through CXCR3 [79]. Furthermore, citrullination of the most $\mathrm{NH}_{2}$-terminal arginine in CXCL10 or CXCL11 reduced their interaction with heparin [80]. At this point it remains to be elucidated whether the negative effect of GAGs on the potency of CXCR3 agonists to induce intracellular calcium release results from competition between chemokines and GAGs for CXCR3 binding or is rooted at the level of signal transduction, where GAGs potentially exert an inhibitory effect either directly or indirectly. Noteworthy, former studies reported that soluble GAGs also significantly reduce the CXCL8, CCL2, CCL3 and CCL5 mediated intracellular calcium mobilization [81]. Specifically, the authors showed that GAGs, in a competitive fashion, bind to chemokine receptors CXCR1, CXCR2 and CCR1. To our notice, no calcium mobilization studies with GAGs, CXCR3 and its chemokine ligands have been conducted before, but we speculate that GAGs may also interact with CXCR3.

Membrane-bound CD26 is a lymphocyte surface marker that is expressed by activated T cells [82]. In our study, we confirmed that cultured $\mathrm{T}$ cells were indeed characterized by CD26 expression and we demonstrated that the expressed enzyme was enzymatically active. Combined with the fact that CXCL10(3-77) is biologically inactive and our observation that GAGs protect CXCL10 against cleavage by CD26, we reasoned that in the presence of GAGs, intact CXCL10 would be preserved, thus resulting in enhanced CXCL10-mediated T cell chemotaxis compared to a condition without GAG. However, we found no significant differences in CXCL10-mediated T cell chemotaxis in vitro in the presence of heparan sulfate and a moderately reduced migration in the presence of heparin. Possibly, this could be explained by the negative effect of GAGs on the CXCL10-CXCR3 dialog. Indeed, it appears that the reduced CXCL10(3-77)-CXCR3 interaction overwrites the inhibitory effect of GAGs on CD26-mediated truncation of intact CXCL10 towards inactive CXCL10(3-77). To investigate the effect of specific inhibition of CD26-mediated cleavage on CXCL10-induced T cell chemotaxis in vitro, we evaluated the effect of administration of the CD26 inhibitor sitagliptin. In contrast to our expectations, no significant increase in CXCL10-directed T cell migration was found in vitro when cells were treated with sitagliptin. However, it was previously demonstrated that sitagliptin treatment in mice resulted in enhanced infiltration of $\mathrm{T}$ cells into the peritoneum or in tumor tissue in vivo [52,63]. Moreover, in the present study, we showed that intra articular injection of CXCL10 in sitagliptin-treated mice significantly enhances lymphocyte recruitment to the joint compared to mice that did not receive the CD26 inhibitor. These observations are in line with the idea that specific CD26 inhibition protects CXCL10 from inactivation in vivo. Indeed, in contrast to what is the case in our in vitro experiments, 
soluble CD26 and membrane-bound CD26 on non-lymphoid cells such as certain endothelial cells, fibroblasts and epithelial cells is present in vivo in addition to T cell-associated membrane-bound CD26 [83]. Therefore, in in vitro chemotaxis experiments, CXCL10 was not hindered by soluble CD26, but could only be inactivated by CD26 when it directly contacted the membrane-bound enzyme. A possible explanation for the lack of a significant effect of sitagliptin-mediated CD26 inhibition on CXCL10-induced chemotaxis in vitro, consequently, could be that CXCL10 was already bound to its receptor prior to interaction with membrane-bound CD26 on T cells. Furthermore, the amount of T cells in our experiments was fixed whereas during inflammation in vivo, for example, the number of activated $T$ cells and consequently the availability of membrane-bound CD26, may drastically increase. Additionally, although we confirmed the CD26 expression and activity on cultured T cells, the CD26 activity on these cells was rather low. Thus, one could speculate that the amount of cell-bound CD26 activity in our in vitro tests was too low.

\section{Materials and Methods}

\subsection{Cells and Reagents}

\subsubsection{Chemokines and CD26}

Full length recombinant human chemokines CXCL9, CXCL10 and CXCL11 were purchased from PeproTech (Rocky Hill, NJ, USA). An Activo-P11 automated solid phase peptide synthesizer (Activotec, Cambridge, UK) was used to chemically synthesize CXCL10, based on N-(9-fluorenyl) methoxycarbonyl (Fmoc) chemistry as described previously [84]. To avoid synthesis problems due to its COOH-terminal proline, a H-Pro-2Cl-Trityl resin (Activotec) was used for synthesis of CXCL10. The synthesized chemokine was purified to homogeneity with reverse phase-high performance liquid chromatography using a Source 5-RPC column $(4.6 \times 150 \mathrm{~mm}$; GE Healthcare, Uppsala, Sweden). An acetonitrile gradient in $0.1 \%(v / v)$ TFA was used for elution of the synthesized protein and $0.7 \%$ of the effluent was directly injected into an electrospray-ion trap mass spectrometer (Bruker AmaZon SL mass spectrometer; Bruker Daltonics, Bremen, Germany). Fractions containing homogenous CXCL10 were selected, pooled, evaporated and dissolved in ultrapure water. Following folding of purified CXCL10 according to the protocol described by Loos et al. [84], the identity of the chemokine was confirmed by ion trap mass spectrometry and automated $\mathrm{NH}_{2}$-terminal sequencing based on the principle of Edman degradation (Procise 491 cLC sequencer, Applied Biosystems, Foster City, CA, USA). In addition, SDS-PAGE and bicinchoninic acid (BCA) protein assays (Pierce, Woodland Hills, CA, USA) were used to determine protein concentrations and purity.

Natural human soluble CD26 was isolated from human seminal fluid and purified to homogeneity by anion exchange and affinity chromatography as described [85].

\subsubsection{Cells}

Chinese hamster ovary cells, stably transfected with CXCR3A (CHO/CXCR3A cells), were a gift from M. Parmentier (Université Libre de Bruxelles, Brussels, Belgium) and were cultured in Ham's F12 medium (Lonza, Basel, Switserland) enriched with $1 \mathrm{mM}$ sodium pyruvate, $400 \mu \mathrm{g} / \mathrm{mL}$ geneticin and $10 \%(v / v)$ fetal calf serum (FCS; Gibco, Paisley, UK). Peripheral blood mononuclear cells (PBMCs) were isolated from buffy coats or from fresh blood after centrifugation $\left(10 \mathrm{~min} ., 20^{\circ} \mathrm{C}, 218 \mathrm{~g}\right)$ in a density gradient (Pancoll human, 1,077 g/mL; PAN Biotech GmbH, Aidenbach, Germany). Isolated PBMCs were washed with phosphate buffered saline (PBS) and cultivated in "Roswell Park Memorial Institute" 1640 (RPMI1640) medium (Cambrex Corporation, East Rutherford, NJ, USA) complemented with 10\% $(v / v) \mathrm{FCS}, 0.1 \%(w / v) \mathrm{NaHCO}_{3}(\mathrm{Gibco})$ and $0.05 \%(w / v)$ gentamycin (Gibco). T cells were activated with $0.002 \%(w / v)$ phytoheamagglutinin L (PHA; Sigma-Aldrich, St. Louis, MO, USA) at $37^{\circ} \mathrm{C}$ during 2-5 days. Activated T cells were stimulated with recombinant human IL-2 (Peprotech) in fresh medium 
every 2-3 days, and were used in experiments 10-20 days after PHA activation and 2 days after IL-2 stimulation.

\subsection{Proteolytic Processing of Chemokines by CD26 In Vitro}

The chemokines CXCL9, CXCL10 or CXCL11 $(20 \mu \mathrm{g} / \mathrm{mL})$ were incubated with 12.5 units per liter (U/L) natural human CD26, with or without 0.88 to $26.4 \mu \mathrm{g} / \mathrm{mL}$ heparin, heparin DP8, heparin DP30, heparan sulfate, dermatan sulfate (Iduron, Chechire, U.K.), chondroitin sulfate A or chondroitin sulfate C (Sigma-Aldrich) in $50 \mathrm{mM}$ EDTA; $1 \mathrm{mM}$ Tris buffer (pH 7.5) in a total volume of $25 \mu \mathrm{L}$ in low-binding tubes (Eppendorf LoBind Tube 1,5 mL, Eppendorf AG, Hamburg, Germany). An overview of the GAGs used in experiments is provided in Table 2. Nota bene, "DP" refers to the number of disaccharides. After $2 \mathrm{~h}$ of incubation, enzymatic reactions were terminated by acidification up to $0.08 \%(v / v)$ TFA. Chemokines were extracted and desalted from total samples on C18 ZipTip pipet tips (Millipore Corporation), eluted with 50\% $(v / v)$ acetonitrile in $0.1 \%(v / v)$ TFA, and analyzed by mass spectrometry.

Table 2. Specifications of GAGs used in experiments.

\begin{tabular}{|c|c|c|c|c|}
\hline GAG & Source & Company & Composition & Relative Molecular Mass $M_{r}$ \\
\hline $\begin{array}{l}\text { Heparin } \\
\text { DP30 }\end{array}$ & Porcine mucosa & Iduron & $\Delta$ HexA,2S-GlcNS,6S-(IdoUA,2S-GlcNS,6S) 30 & $>9 \mathrm{kDa}^{\mathrm{b}}$ \\
\hline $\begin{array}{l}\text { Heparin } \\
\text { DP8 }\end{array}$ & Porcine mucosa & Iduron & $\Delta$ HexA,2S-GlcNS,6S-(IdoUA,2S-GlcNS,6S) 8 & $\pm 2.4 \mathrm{kDa}^{\mathrm{b}}$ \\
\hline $\begin{array}{l}\text { Dermatan } \\
\text { sulfate }\end{array}$ & Porcine mucosa & Iduron & $\begin{array}{l}\text { HexA-GalNAc,4S (88\%); HexA-GalNAc (5\%); } \\
\text { HexA,2S-GalNAc,4S (7\%) }\end{array}$ & $\pm 41 \mathrm{kDa}^{\mathrm{b}}$ \\
\hline $\begin{array}{l}\text { Chondroitin } \\
\text { sulfate A }\end{array}$ & Bovine trachea & Sigma-Aldrich & $\begin{array}{c}\text { Alternating Copoly } \beta \text {-glucuronic } \\
\text { acid- }(1 \rightarrow 3)-N \text {-acetyl- } \beta \text {-galactosamine- } 4 \text {-sulfate- }(1 \rightarrow 4)\end{array}$ & $\pm 40 \mathrm{kDa}^{\mathrm{a}}$ \\
\hline
\end{tabular}

\subsection{CD26 Activity Assays}

In a flat bottom 96 well plate, (Greiner Bio-One, Kremsmünster, Austria), 5 U/L purified natural human CD26 was incubated with $500 \mu \mathrm{M}$ of the substrate Gly-Pro-p-nitroanilide (Gly-Pro-pNA; Sigma-Aldrich), with or without GAG, in $0.22 \mu \mathrm{m}$-filtered $75 \mathrm{mM}$ Tris-HCl buffer (pH 8.3). Evolution of the optic density (OD) at $405 \mathrm{~nm}$ was followed using a spectrophotometer (BioTek PowerWave XS, Winooski, VT, USA) and represented the kinetics of CD26-mediated enzymatic conversion of colorless Gly-Pro-pNA into yellowish pNA. OD measurements were performed at $37^{\circ} \mathrm{C}$ every 5 min for $3 \mathrm{~h}$. CD26 activity curves were constructed by plotting OD values against time. Slopes of activity curves reflected the number of converted substrate molecules per min and were used to calculate enzymatic activities in U/L using the Lambert-Beer law. CD26 activity assays were also used to investigate the CD26 activity of PHA-activated T cells. Briefly, $10^{4}$ to $3 \times 10^{6} \mathrm{~T}$ cells per $\mathrm{mL}$ in $75 \mathrm{mM}$ Tris-HCl buffer (pH 8.3), with or without $20 \mu \mathrm{M}$ to $2 \mathrm{mM}$ sitagliptin (Merck Sharpe \& Dohme (MSD) Whitehouse Station, NJ, USA), were incubated with $500 \mu \mathrm{M}$ Gly-Pro pNA and the same protocol was followed.

\subsection{Calcium-Mobilization Assays}

CHO/CXCR3A cells $\left(10 \times 10^{6}\right.$ per $\left.\mathrm{mL}\right)$ in Ham's F12 medium (Lonza) containing $10 \%(v / v)$ FCS were treated with $2.5 \mu \mathrm{M}$ of the fluorescent dye Fura-2AM (Invitrogen, Carlsbad, CA, USA), 0.01\% $(w / v)$ Pluronic-F127 (Sigma) and $125 \mu$ M Probenecid solution (ICN Biomedicals Inc., Aurora, OH, USA) for $30 \mathrm{~min}$ at room temperature. Cells were washed with Ham's F12 medium containing $10 \%(v / v)$ FCS, 
centrifuged $\left(10 \mathrm{~min}, 4{ }^{\circ} \mathrm{C}, 177 \mathrm{~g}\right.$ ) and suspended in $\mathrm{pH} 7.0 \mathrm{Ca}^{2+}$ buffer ("Hanks Balanced Salt Solution" (HBSS; Invitrogen) containing $\mathrm{Ca}^{2+}$ and $\mathrm{Mg}^{2+}$ and complemented with $10 \mathrm{mM}$ HEPES (Gibco) and $0.1 \%$ $(v / v)$ FCS) enriched with $125 \mu \mathrm{M}$ Probenecid. Cells were kept on ice, centrifuged ( $\left.10 \mathrm{~min}, 4^{\circ} \mathrm{C}, 177 \mathrm{~g}\right)$, and suspended in $\mathrm{Ca}^{2+}$ buffer with Probenecid at final concentrations of $10^{6}$ cells per mL. An LS50 B luminescence spectrometer (Perkin Elmer, Waltham, MA, USA) was used to measure fluorescence and intracellular $\mathrm{Ca}^{2+}$ concentrations $\left(\left[\mathrm{Ca}^{2+}\right]_{\mathrm{i}}\right)$ were calculated using the Grynkiewicz equation [86]. For each individual test condition, $1.8 \times 10^{6}$ cells were preheated for $10 \mathrm{~min}$ at $30^{\circ} \mathrm{C}$, followed by stimulation with 3 to $1000 \mathrm{ng} / \mathrm{mL}$ CXCL9, CXCL10 or CXCL11, with or without $0.04 \mu \mathrm{g} / \mathrm{mL}$, $2 \mu \mathrm{g} / \mathrm{mL}$ or $10 \mu \mathrm{g} / \mathrm{mL}$ GAG. $R_{\max }$ and $R_{\min }$ values were determined via treatment of cells with $50 \mu \mathrm{M}$ digitonin and 10 mM EGTA (Sigma-Aldrich) in 20 mM Tris (pH 8.5; Merck, Darmstadt, Germany), respectively. Results were analyzed with WinLab32 software (Perkin Elmer). Fluorescence intensities of unloaded cells (not treated with Fura-2AM) were used to correct results for auto-fluorescence intrinsic to $\mathrm{CHO} / \mathrm{CXCR} 3 \mathrm{~A}$ cells.

\subsection{In Vitro Chemotaxis Assays}

In vitro, 48-well Boyden chamber cell migration assays were used to determine chemotaxis of PHA-activated T cells in response to CXCL10 with or without GAG [87]. Briefly, CXCL10 and $\mathrm{T}$ cells were diluted in HBSS buffer enriched with $0.5 \%(v / v)$ human serum albumin (HSA; Red Cross Blood transfusion center, Leuven, Belgium). Wells in the lower part of the chamber were filled with 10-300 $\mathrm{ng} / \mathrm{mL}$ CXCL10 with or without $0.04 \mathrm{or} 4 \mu \mathrm{g} / \mathrm{mL} \mathrm{GAG}$ in a total volume of $30 \mu \mathrm{L}$ per well. Buffer without chemokine or GAG was used as a negative control. The lower chamber was covered with a $5 \mu \mathrm{m}$ polycarbonate membrane (Nuclepore Track-Etch Membrane, Whatman, Little Chalfont, UK) that was treated with $20 \mu \mathrm{g} / \mathrm{mL}$ fibronectin (Gibco) in PBS overnight. The upper part of the chamber was filled with $2 \times 10^{6} \mathrm{~T}$ cells per $\mathrm{mL}$ in buffer ( $50 \mu \mathrm{L}$ per well), with or without $200 \mu \mathrm{M}$ sitagliptin. Following $3 \mathrm{~h}$ of incubation at $37^{\circ} \mathrm{C}$, membranes were fixed and stained (Hemacolor Solution I-III, Merck). For each individual test condition, numbers of migrated T cells were counted microscopically in 10 separate fields. Chemotactic indices were determined by dividing total numbers of $\mathrm{T}$ cells that migrated to the sample through the total number of cells that migrated in response to buffer alone.

\subsection{In Vivo Cell Migration Assay}

The effect of CD26 inhibition on lymphocyte attraction was determined after intra-articular (i.a.) injection of human CXCL10 as described by Janssens et al. [88]. Briefly, the drinking water of 8-week-old C57BL/ 6 mice was complemented with $1.7 \mathrm{mg} / \mathrm{mL}$ sitagliptin from 3 days prior to i.a. injection of $1 \mu \mathrm{g}$ synthetic full length CXCL10 diluted in $0.9 \%(w / v) \mathrm{NaCl}$. A Limulus amoebocyte lysate assay (Cambrex) demonstrated that endotoxin levels in injected samples were lower than 0.125 pg LPS per $\mu \mathrm{g}$ chemokine. During injection of $10 \mu \mathrm{L}$ of the CXCL10 dilution, mice were anaesthetized using 3.75\% $(w / v)$ ketamine plus $0.25 \%(w / v)$ xylazine in PBS. Mice were sacrificed after $3 \mathrm{~h}$ of incubation, and articular cavities were washed with $3 \%(w / v)$ BSA in PBS. Total leukocyte numbers were calculated after staining with Turk's solution in a Neubauer chamber, followed by differential counting of samples on cytospins that were stained with May-Grünwald-Giemsa. All in vivo experiments were conducted in the animal research facility of the University of Minas Gerais after approval by the Animal Ethical Committee.

\subsection{Flow Cytometry}

Flow cytometry was used to confirm the CXCR3 and CD26 expression of cultivated T cells. Tubes were filled with $3 \times 10^{5}$ cells and centrifuged $\left(5 \mathrm{~min}, 4^{\circ} \mathrm{C}, 315 \mathrm{~g}\right.$ ). Supernatant was removed and cells were suspended in PBS containing Fc block (MACS Miltenyi Biotec, Bergisch Gladbach, Germany) and Aqua Zombie-BV510 (Biolegend, San Diego, CA, USA), according to the recommendations of the companies. Following $15 \mathrm{~min}$ of incubation at $20{ }^{\circ} \mathrm{C}$, cells were centrifuged $\left(5 \mathrm{~min}, 4{ }^{\circ} \mathrm{C}\right.$, 
$315 \mathrm{~g}$ ) and pellets were suspended in flow cytometry buffer (PBS containing 2\% $(v / v)$ FCS and $2 \mathrm{mM}$ EDTA). Samples were centrifuged $\left(5 \mathrm{~min}, 4^{\circ} \mathrm{C}, 315 \mathrm{~g}\right.$ ) and cells were diluted in fresh buffer. For each sample, recommended amounts of BV421-labeled anti-human CXCR3, PE-labeled anti-human CD3, PerCP-Cy5.5-labeled anti-human CD14, FITC-labeled anti-human CD26 (BD Pharmingen, San Diego, CA, USA) or APC-labeled anti-human CD14 (Biolegend), were added. Combined stainings were conducted with anti-CD3-PE, anti-CXCR3-BV421, anti-CD26-FITC and anti-CD14-PerCP-Cy5.5; anti-CD3-PE, anti-CXCR3-BV421 and anti-CD26-FITC; anti-CD3, anti-CD3-PE, anti-CXCR3-BV421 and anti-CD14-PerCP-Cy5.5 and finally with anti-CD3-PE, anti-CXCR3-BV421 and anti-CD14-APC. Isotype controls were performed to exclude non-specific binding. Untreated cells were used as negative controls. One sample of unstained cells was heated at $56{ }^{\circ} \mathrm{C}$ for $10-15$ min to kill part of the cells, and served as a positive control for the Aqua Zombie staining. Antibody-treated cells were kept at $4{ }^{\circ} \mathrm{C}$ for $30 \mathrm{~min}$, and were, respectively, suspended in flow cytometry buffer, centrifuged $\left(5 \mathrm{~min}, 4^{\circ} \mathrm{C}\right.$, $315 \mathrm{~g}$ ) and decanted 3 times in a row. Resulting pellets were diluted in fixation buffer (flow cytometry buffer plus $0.04 \%(w / v)$ paraformaldehyde) and fluorescence intensities were determined with a BD LSRFORTESSA X-20 flow cytometer (BD Biosciences, Franklin Lakes, NJ, USA) equipped with 5 lasers. Results were analyzed with FlowJo software.

\subsection{Statistics}

Mann-Whitney $U$ tests were performed to evaluate whether results of unpaired groups were significantly different or not. A $p$ value of 0.05 or less was considered significant.

Supplementary Materials: Supplementary materials can be found at www.mdpi.com/1422-0067/18/7/1513/s1.

Acknowledgments: This research was financially supported by the Interuniversity Attraction Poles Programme initiated by the Belgian Science Policy Office (I.A.P. Project 7/40), the Fund for Scientific Research of Flanders, the Brazilian National Council for Scientific and Technological Development (CNPq) and the Concerted Research Actions of the Regional Government of Flanders (GOA/12/017) and C1 funding from KU Leuven. The Hercules foundation of the Flemish government funded the purchase of LC-MS/MS equipment (Contract AKUL/11/31). AM obtained a postdoctoral research scholarship of the FWO-Vlaanderen

Author Contributions: Mieke Metzemaekers, Anneleen Mortier, Rik Janssens, Daiane Boff, Lotte Vanbrabant, Flávio A. Amaral and Paul Proost performed experiments; Nicole Lamoen purified natural CD26 enzyme; Mieke Metzemaekers, Anneleen Mortier and Paul Proost wrote the manuscript; Mieke Metzemaekers, Anneleen Mortier, Jo Van Damme, Mauro M. Teixeira, Ingrid De Meester, Flávio A. Amaral and Paul Proost designed the study and were responsible for data interpretation and manuscript correction. All authors approved the final version of the manuscript.

Conflicts of Interest: The authors declare no conflict of interest.

\section{Abbreviations}

$\left[\mathrm{Ca}^{2+}\right]_{\mathrm{i}}$ Intracellular calcium concentration

GAG glycosaminoglycan

GPCR G protein-coupled receptor

$\mathrm{M}_{\mathrm{r}} \quad$ Relative molecular mass

\section{References}

1. Zlotnik, A.; Yoshie, O. The chemokine superfamily revisited. Immunity 2012, 36, 705-716. [CrossRef] [PubMed]

2. Blanchet, X.; Langer, M.; Weber, C.; Koenen, R.R.; von Hundelshausen, P. Touch of chemokines. Front. Immunol. 2012, 3, 175. [CrossRef] [PubMed]

3. Romagnani, P.; Lasagni, L.; Annunziato, F.; Serio, M.; Romagnani, S. CXC chemokines: The regulatory link between inflammation and angiogenesis. Trends Immunol. 2004, 25, 201-209. [CrossRef] [PubMed]

4. Russo, R.C.; Garcia, C.C.; Teixeira, M.M.; Amaral, F.A. The CXCL8/IL-8 chemokine family and its receptors in inflammatory diseases. Expert. Rev. Clin. Immunol. 2014, 10, 593-619. [CrossRef] [PubMed] 
5. Keeley, E.C.; Mehrad, B.; Strieter, R.M. Chemokines as mediators of tumor angiogenesis and neovascularization. Exp. Cell Res. 2011, 317, 685-690. [CrossRef] [PubMed]

6. Bachelerie, F.; Ben-Baruch, A.; Burkhardt, A.M.; Combadiere, C.; Farber, J.M.; Graham, G.J.; Horuk, R.; Sparre-Ulrich, A.H.; Locati, M.; Luster, A.D.; et al. International union of basic and clinical pharmacology. LXXXIX. Update on the extended family of chemokine receptors and introducing a new nomenclature for atypical chemokine receptors. Pharmacol. Rev. 2014, 66, 1-79. [CrossRef] [PubMed]

7. Corsiero, E.; Nerviani, A.; Bombardieri, M.; Pitzalis, C. Ectopic lymphoid structures: Powerhouse of autoimmunity. Front. Immunol. 2016, 7, 430. [CrossRef] [PubMed]

8. Opdenakker, G.; Proost, P.; Van Damme, J. Microbiomic and posttranslational modifications as preludes to autoimmune diseases. Trends Mol. Med. 2016, 22, 746-757. [CrossRef] [PubMed]

9. Rot, A.; von Andrian, U.H. Chemokines in innate and adaptive host defense: Basic chemokinese grammar for immune cells. Annu. Rev. Immunol. 2004, 22, 891-928. [CrossRef] [PubMed]

10. Groom, J.R.; Luster, A.D. CXCR3 ligands: Redundant, collaborative and antagonistic functions. Immunol. Cell Biol. 2011, 89, 207-215. [CrossRef] [PubMed]

11. Van Raemdonck, K.; Van den Steen, P.E.; Liekens, S.; Van Damme, J.; Struyf, S. CXCR3 ligands in disease and therapy. Cytokine Growth Factor Rev. 2015, 26, 311-327. [CrossRef] [PubMed]

12. Groom, J.R.; Luster, A.D. CXCR3 in T cell function. Exp. Cell Res. 2011, 317, 620-631. [CrossRef] [PubMed]

13. Lasagni, L.; Francalanci, M.; Annunziato, F.; Lazzeri, F.; Giannini, S.; Cosmi, L.; Sagrinati, C.; Mazzinghi, B.; Orlando, C.; Maggi, E.; et al. An alternatively spliced variant of CXCR3 mediates the inhibition of endothelial cell growth induced by IP-10, Mig, and I-TAC, and acts as functional receptor for platelet factor 4. J. Exp. Med. 2003, 197, 1537-1549. [CrossRef] [PubMed]

14. Naumann, U.; Cameroni, E.; Pruenster, M.; Mahabaleshwar, H.; Raz, E.; Zerwes, H.G.; Rot, A.; Thelen, M. CXCR7 functions as a scavenger for CXCL12 and CXCL11. PLoS ONE 2010, 5, e9175. [CrossRef] [PubMed]

15. Girard, M.; Rhainds, D.; St-Onge, G. Mutational analysis of atypical chemokine receptor 3 (ACKR3/CXCR7) interaction with its chemokine ligands CXCL11 and CXCL12. J. Biol. Chem. 2017, 292, 31-42.

16. Burns, J.M.; Summers, B.C.; Wang, Y.; Melikian, A.; Berahovich, R.; Miao, Z.; Penfold, M.E.; Sunshine, M.J.; Littman, D.R.; Kuo, C.J.; et al. A novel chemokine receptor for SDF-1 and I-TAC involved in cell survival, cell adhesion, and tumor development. J. Exp. Med. 2006, 203, 2201-2213. [CrossRef] [PubMed]

17. Vanheule, V.; Janssens, R.; Boff, D.; Kitic, N.; Berghmans, N.; Ronsse, I.; Kungl, A.J.; Amaral, F.A.; Teixeira, M.M.; Van Damme, J.; et al. The Positively charged COOH-terminal glycosaminoglycan-binding CXCL9(74-103) peptide inhibits CXCL8-induced neutrophil extravasation and monosodium urate crystal-induced gout in mice. J. Biol. Chem. 2015, 290, 21292-21304. [CrossRef] [PubMed]

18. Farber, J.M. Mig and IP-10: CXC chemokines that target lymphocytes. J. Leukoc. Biol. 1997, 61, $246-257$. [PubMed]

19. Ohmori, Y.; Schreiber, R.D.; Hamilton, T.A. Synergy between interferon-gamma and tumor necrosis factor- $\alpha$ in transcriptional activation is mediated by cooperation between signal transducer and activator of transcription 1 and nuclear factor кB. J. Biol. Chem. 1997, 272, 14899-14907. [CrossRef] [PubMed]

20. Ohmori, Y.; Wyner, L.; Narumi, S.; Armstrong, D.; Stoler, M.; Hamilton, T.A. Tumor necrosis factoralpha induces cell type and tissue-specific expression of chemoattractant cytokines in vivo. Am. J. Pathol. 1993, 142, 861-870. [PubMed]

21. Rani, M.R.; Foster, G.R.; Leung, S.; Leaman, D.; Stark, G.R.; Ransohoff, R.M. Characterization of $\beta-R 1$, a gene that is selectively induced by interferon $\beta$ (IFN- $\beta$ ) compared with IFN- $\alpha$. J. Biol. Chem. 1996, 271, 22878-22884. [CrossRef] [PubMed]

22. Proost, P.; Struyf, S.; Loos, T.; Gouwy, M.; Schutyser, E.; Conings, R.; Ronsse, I.; Parmentier, M.; Grillet, B.; Opdenakker, G.; et al. Coexpression and interaction of CXCL10 and CD26 in mesenchymal cells by synergising inflammatory cytokines: CXCL8 and CXCL10 are discriminative markers for autoimmune arthropathies. Arthritis Res. Ther. 2006, 8, R107. [CrossRef] [PubMed]

23. Proost, P.; Vynckier, A.K.; Mahieu, F.; Put, W.; Grillet, B.; Struyf, S.; Wuyts, A.; Opdenakker, G.; Van Damme, J. Microbial Toll-like receptor ligands differentially regulate CXCL10/IP-10 expression in fibroblasts and mononuclear leukocytes in synergy with IFN- $\gamma$ and provide a mechanism for enhanced synovial chemokine levels in septic arthritis. Eur. J. Immunol. 2003, 33, 3146-3153. [CrossRef] [PubMed] 
24. Hsieh, M.F.; Lai, S.L.; Chen, J.P.; Sung, J.M.; Lin, Y.L.; Wu-Hsieh, B.A.; Gerard, C.; Luster, A.; Liao, F. Both CXCR3 and CXCL10/IFN-inducible protein 10 are required for resistance to primary infection by dengue virus. J. Immunol. 2006, 177, 1855-1863. [CrossRef] [PubMed]

25. Christen, U.; McGavern, D.B.; Luster, A.D.; von Herrath, M.G.; Oldstone, M.B. Among CXCR3 chemokines, IFN- $\gamma$-inducible protein of $10 \mathrm{kDa}$ (CXC chemokine ligand (CXCL) 10) but not monokine induced by IFN- $\gamma$ (CXCL9) imprints a pattern for the subsequent development of autoimmune disease. J. Immunol. 2003, 171, 6838-6845. [CrossRef] [PubMed]

26. Li, B.; Xu, W.; Xu, L.; Jiang, Z.; Wen, Z.; Li, K.; Xiong, S. I-TAC is a dominant chemokine in controlling skin intragraft inflammation via recruiting CXCR3+ cells into the graft. Cell. Immunol. 2010, 260, 83-91. [CrossRef] [PubMed]

27. Klein, R.S.; Lin, E.; Zhang, B.; Luster, A.D.; Tollett, J.; Samuel, M.A.; Engle, M.; Diamond, M.S. Neuronal CXCL10 directs CD8+ T-cell recruitment and control of West Nile virus encephalitis. J. Virol. 2005, 79, 11457-11466. [CrossRef] [PubMed]

28. Campanella, G.S.; Tager, A.M.; EI Khoury, J.K.; Thomas, S.Y.; Abrazinski, T.A.; Manice, L.A.; Colvin, R.A.; Luster, A.D. Chemokine receptor CXCR3 and its ligands CXCL9 and CXCL10 are required for the development of murine cerebral malaria. Proc. Natl. Acad. Sci. USA 2008, 105, 4814-4819. [CrossRef] [PubMed]

29. Thapa, M.; Welner, R.S.; Pelayo, R.; Carr, D.J. CXCL9 and CXCL10 expression are critical for control of genital herpes simplex virus type 2 infection through mobilization of HSV-specific CTL and NK cells to the nervous system. J. Immunol. 2008, 180, 1098-1106. [CrossRef] [PubMed]

30. Rosenblum, J.M.; Shimoda, N.; Schenk, A.D.; Zhang, H.; Kish, D.D.; Keslar, K.; Farber, J.M.; Fairchild, R.L. CXC chemokine ligand (CXCL) 9 and CXCL10 are antagonistic costimulation molecules during the priming of alloreactive T cell effectors. J. Immunol. 2010, 184, 3450-3460. [CrossRef] [PubMed]

31. Sierro, F.; Biben, C.; Martínez-Muñoz, L.; Mellado, M.; Ransohoff, R.M.; Li, M.; Woehl, B.; Leung, H.; Groom, J.; Batten, M.; et al. Disrupted cardiac development but normal hematopoiesis in mice deficient in the second CXCL12/SDF-1 receptor, CXCR7. Proc. Natl. Acad. Sci. USA 2007, 104, 14759-14764. [CrossRef] [PubMed]

32. Sarris, M.; Masson, J.B.; Maurin, D.; Van der Aa, L.M.; Boudinot, P.; Lortat-Jacob, H.; Herbomel, P. Inflammatory chemokines direct and restrict leukocyte migration within live tissues as glycan-bound gradients. Curr. Biol. 2012, 22, 2375-2382. [CrossRef] [PubMed]

33. Proudfoot, A.E.; Handel, T.M.; Johnson, Z.; Lau, E.K.; LiWang, P.; Clark-Lewis, I.; Borlat, F.; Wells, T.N.; Kosco-Vilbois, M.H. Glycosaminoglycan binding and oligomerization are essential for the in vivo activity of certain chemokines. Proc. Natl. Acad. Sci. USA 2003, 100, 1885-1890. [CrossRef] [PubMed]

34. Wang, L.; Fuster, M.; Sriramarao, P.; Esko, J.D. Endothelial heparan sulfate deficiency impairs L-selectin- and chemokine-mediated neutrophil trafficking during inflammatory responses. Nat. Immunol. 2005, 6, 902-910. [CrossRef] [PubMed]

35. Severin, I.C.; Gaudry, J.P.; Johnson, Z.; Kungl, A.; Jansma, A.; Gesslbauer, B.; Mulloy, B.; Power, C.; Proudfoot, A.E.; Handel, T. Characterization of the chemokine CXCL11-heparin interaction suggests two different affinities for glycosaminoglycans. J. Biol. Chem. 2010, 285, 17713-17724. [CrossRef] [PubMed]

36. Campanella, G.S.; Grimm, J.; Manice, L.A.; Colvin, R.A.; Medoff, B.D.; Wojtkiewicz, G.R.; Weissleder, R.; Luster, A.D. Oligomerization of CXCL10 is necessary for endothelial cell presentation and in vivo activity. J. Immunol. 2006, 177, 6991-6998. [CrossRef] [PubMed]

37. Massena, S.; Christoffersson, G.; Hjertström, E.; Zcharia, E.; Vlodavsky, I.; Ausmees, N.; Rolny, C.; Li, J.P.; Phillipson, M. A chemotactic gradient sequestered on endothelial heparan sulfate induces directional intraluminal crawling of neutrophils. Blood 2010, 116, 1924-1931. [CrossRef] [PubMed]

38. Bao, X.; Moseman, E.A.; Saito, H.; Petryanik, B.; Thiriot, A.; Hatakeyama, S.; Ito, Y.; Kawashima, H.; Yamaguchi, Y.; Lowe, J.B.; et al. Endothelial heparan sulfate controls chemokine presentation in recruitment of lymphocytes and dendritic cells to lymph nodes. Immunity 2010, 33, 817-829. [CrossRef] [PubMed]

39. Kumar, A.V.; Katakam, S.K.; Urbanowitz, A.K.; Gotte, M. Heparan sulfate as a regulator of leukocyte recruitment in inflammation. Curr. Protein Pept. Sci. 2015, 16, 77-86. [CrossRef] [PubMed]

40. Xu, D.; Esko, J.D. Demystifying heparan sulfate-protein interactions. Annu. Rev. Biochem. 2014, 83, $129-157$. [CrossRef] [PubMed] 
41. Vanheule, V.; Vervaeke, P.; Mortier, A.; Noppen, S.; Gouwy, M.; Snoeck, R.; Andrei, G.; Van Damme, J.; Liekens, S.; Proost, P. Basic chemokine-derived glycosaminoglycan binding peptides exert antiviral properties against dengue virus serotype 2, herpes simplex virus-1 and respiratory syncytial virus. Biochem. Pharmacol. 2016, 100, 73-85. [CrossRef] [PubMed]

42. Baggiolini, M. CXCL8-The First Chemokine. Front. Immunol. 2015, 6, 285. [CrossRef] [PubMed]

43. Van Damme, J.; Van Beeumen, J.; Conings, R.; Decock, B.; Billiau, A. Purification of granulocyte chemotactic peptide/interleukin- 8 reveals $\mathrm{N}$-terminal sequence heterogeneity similar to that of beta-thromboglobulin. Eur. J. Biochem. 1989, 181, 337-344. [CrossRef] [PubMed]

44. Mortier, A.; Van Damme, J.; Proost, P. Overview of the mechanisms regulating chemokine activity and availability. Immunol. Lett. 2012, 145, 2-9.

45. Krohn, S.C.; Bonvin, P.; Proudfoot, A.E. CCL18 exhibits a regulatory role through inhibition of receptor and glycosaminoglycan binding. PLoS ONE 2013, 8, e72321. [CrossRef] [PubMed]

46. Sadir, R.; Imberty, A.; Baleux, F.; Lortat-Jacob, H. Heparan sulfate/heparin oligosaccharides protect stromal cell-derived factor-1 (SDF-1)/CXCL12 against proteolysis induced by CD26/dipeptidyl peptidase IV. J. Biol. Chem. 2004, 279, 43854-43860. [CrossRef] [PubMed]

47. Ellyard, J.I.; Simson, L.; Bezos, A.; Johnston, K.; Freeman, C.; Parish, C.R. Eotaxin selectively binds heparin. An interaction that protects eotaxin from proteolysis and potentiates chemotactic activity in vivo. J. Biol. Chem. 2007, 282, 15238-15247. [CrossRef] [PubMed]

48. Mortier, A.; Gouwy, M.; Van Damme, J.; Proost, P. Effect of posttranslational processing on the in vitro and in vivo activity of chemokines. Exp. Cell Res. 2011, 317, 642-654. [CrossRef] [PubMed]

49. Moelants, E.A.; Mortier, A.; Van Damme, J.; Proost, P. In vivo regulation of chemokine activity by post-translational modification. Immunol. Cell Biol. 2013, 91, 402-407. [CrossRef] [PubMed]

50. Metzemaekers, M.; Van Damme, J.; Mortier, A.; Proost, P. Regulation of chemokine activity-A focus on the role of dipeptidyl peptidase IV/CD26. Front. Immunol. 2016, 7, 483. [CrossRef] [PubMed]

51. Janssens, R.; Mortier, A.; Boff, D.; Ruytinx, P.; Gouwy, M.; Vantilt, B.; Larsen, O.; Daugvilaite, V.; Rosenkilde, M.M.; Parmentier, M.; et al. Truncation of CXCL12 by CD26 reduces its CXC chemokine receptor 4- and atypical chemokine receptor 3-dependent activity on endothelial cells and lymphocytes. Biochem. Pharmacol. 2017, 132, 92-101. [CrossRef] [PubMed]

52. Mortier, A.; Gouwy, M.; Van Damme, J.; Proost, P.; Struyf, S. CD26/dipeptidylpeptidase IV-chemokine interactions: Double-edged regulation of inflammation and tumor biology. J. Leukoc. Biol. 2016, 99, 955-969. [CrossRef] [PubMed]

53. Proost, P.; Schutyser, E.; Menten, P.; Struyf, S.; Wuyts, A.; Opdenakker, G.; Detheux, M.; Parmentier, M.; Durinx, C.; Lambeir, A.M.; et al. Amino-terminal truncation of CXCR3 agonists impairs receptor signaling and lymphocyte chemotaxis, while preserving antiangiogenic properties. Blood 2001, 98, 3554-3561. [CrossRef] [PubMed]

54. Lambeir, A.M.; Durinx, C.; Scharpé, S.; De Meester, I. Dipeptidyl-peptidase IV from bench to bedside: An update on structural properties, functions, and clinical aspects of the enzyme DPP IV. Crit. Rev. Clin. Lab. Sci. 2003, 40, 209-294. [CrossRef] [PubMed]

55. Klemann, C.; Wagner, L.; Stephan, M.; von Hörsten, S. Cut to the chase: A review of CD26/dipeptidyl peptidase-4's (DPP4) entanglement in the immune system. Clin. Exp. Immunol. 2016, 185, 1-21. [CrossRef] [PubMed]

56. Wagner, L.; Klemann, C.; Stephan, M.; von Hörsten, S. Unravelling the immunological roles of dipeptidyl peptidase 4 (DPP4) activity and/or structure homologue (DASH) proteins. Clin. Exp. Immunol. 2016, 184, 265-283. [CrossRef] [PubMed]

57. Boonacker, E.; Van Noorden, C.J. The multifunctional or moonlighting protein CD26/DPPIV. Eur. J. Cell Biol. 2003, 82, 53-73. [CrossRef] [PubMed]

58. Proost, P.; De Wolf-Peeters, C.; Conings, R.; Opdenakker, G.; Billiau, A.; Van Damme, J. Identification of a novel granulocyte chemotactic protein (GCP-2) from human tumor cells. In vitro and in vivo comparison with natural forms of GRO, IP-10, and IL-8., IP-10, and IL-8. J. Immunol. 1993, 150, 1000-1010. [PubMed]

59. Ludwig, A.; Schiemann, F.; Mentlein, R.; Lindner, B.; Brandt, E. Dipeptidyl peptidase IV (CD26) on T cells cleaves the CXC chemokine CXCL11 (I-TAC) and abolishes the stimulating but not the desensitizing potential of the chemokine. J. Leukoc. Biol. 2002, 72, 183-191. [PubMed] 
60. Proost, P.; Mortier, A.; Loos, T.; Vandercappellen, J.; Gouwy, M.; Ronsse, I.; Schutyser, E.; Put, W.; Parmentier, M.; Struyf, S.; et al. Proteolytic processing of CXCL11 by CD13/aminopeptidase N impairs CXCR3 and CXCR7 binding and signaling and reduces lymphocyte and endothelial cell migration. Blood 2007, 110, 37-44. [CrossRef] [PubMed]

61. Hensbergen, P.J.; van der Raaij-Helmer, E.M.; Dijkman, R.; van der Schors, R.C.; Werner-Felmayer, G.; Boorsma, D.M.; Scheper, R.J.; Willemze, R.; Tensen, C.P. Processing of natural and recombinant CXCR3-targeting chemokines and implications for biological activity. Eur. J. Biochem. 2001, 268, 4992-4999. [CrossRef] [PubMed]

62. Lambeir, A.M.; Proost, P.; Durinx, C.; Bal, G.; Senten, K.; Augustyns, K.; Scharpé, S.; Van Damme, J.; De Meester, I. Kinetic investigation of chemokine truncation by CD26/dipeptidyl peptidase IV reveals a striking selectivity within the chemokine family. J. Biol. Chem. 2001, 276, 29839-29845. [CrossRef] [PubMed]

63. Barreira da Silva, R.; Laird, M.E.; Yatim, N.; Fiette, L.; Ingersoll, M.A.; Albert, M.L. Dipeptidylpeptidase 4 inhibition enhances lymphocyte trafficking, improving both naturally occurring tumor immunity and immunotherapy. Nat. Immunol. 2015, 16, 850-858. [CrossRef] [PubMed]

64. Bleul, C.C.; Fuhlbrigge, R.C.; Casasnovas, J.M.; Aiuti, A.; Springer, T.A. A highly efficacious lymphocyte chemoattractant, stromal cell-derived factor 1 (SDF-1). J. Exp. Med. 1996, 184, 1101-1109. [CrossRef] [PubMed]

65. Lim, K.; Hyun, Y.M.; Lambert-Emo, K.; Capece, T.; Bae, S.; Miller, R.; Topham, D.J.; Kim, M. Neutrophil trails guide influenza-specific CD8(+) T cells in the airways. Science 2015, 349, aaa4352. [CrossRef] [PubMed]

66. Möhle, R.; Bautz, F.; Rafii, S.; Moore, M.A.; Brugger, W.; Kanz, L. The chemokine receptor CXCR-4 is expressed on CD34+ hematopoietic progenitors and leukemic cells and mediates transendothelial migration induced by stromal cell-derived factor-1. Blood 1998, 91, 4523-4530. [PubMed]

67. Aiuti, A.; Webb, I.J.; Bleul, C.C.; Springer, T.; Gutierrez-Ramos, J.C. The chemokine SDF-1 is a chemoattractant for human $\mathrm{CD} 34+$ hematopoietic progenitor cells and provides a new mechanism to explain the mobilization of CD34+ progenitors to peripheral blood. J. Exp. Med. 1997, 185, 111-120. [CrossRef] [PubMed]

68. Shioda, T.; Kato, H.; Ohnishi, Y.; Tashiro, K.; Ikegawa, M.; Nakayama, E.E.; Hu, H.; Kato, A.; Sakai, Y.; Liu, H.; et al. Anti-HIV-1 and chemotactic activities of human stromal cell-derived factor 1alpha (SDF-1 $\alpha$ ) and SDF-1 $\beta$ are abolished by CD26/dipeptidyl peptidase IV-mediated cleavage. Proc. Natl. Acad. Sci. USA 1998, 95, 6331-6336. [CrossRef] [PubMed]

69. Proost, P.; Struyf, S.; Schols, D.; Durinx, C.; Wuyts, A.; Lenaerts, J.P.; De Clercq, E.; De Meester, I.; Van Damme, J. Processing by CD26/dipeptidyl-peptidase IV reduces the chemotactic and anti-HIV-1 activity of stromal-cell-derived factor-1 $\alpha$. FEBS Lett. 1998, 432, 73-76. [CrossRef]

70. Ziarek, J.J.; Veldkamp, C.T.; Zhang, F.; Murray, N.J.; Kartz, G.A.; Liang, X.; Su, J.; Baker, J.E.; Linhardt, R.J.; Volkman, B.F. Heparin oligosaccharides inhibit chemokine (CXC motif) ligand 12 (CXCL12) cardioprotection by binding orthogonal to the dimerization interface, promoting oligomerization, and competing with the chemokine (CXC motif) receptor 4 (CXCR4) N terminus. J. Biol. Chem. 2013, 288, 737-746. [CrossRef] [PubMed]

71. Gangavarapu, P.; Rajagopalan, L.; Kolli, D.; Guerrero-Plata, A.; Garofalo, R.P.; Rajarathnam, K. The monomer-dimer equilibrium and glycosaminoglycan interactions of chemokine CXCL8 regulate tissue-specific neutrophil recruitment. J. Leukoc. Biol. 2012, 91, 259-265. [CrossRef] [PubMed]

72. Dyer, D.P.; Migliorini, E.; Salanga, C.L.; Thakar, D.; Handel, T.M.; Richter, R.P. Differential structural remodelling of heparan sulfate by chemokines: The role of chemokine oligomerization. Open Biol. 2017, 7, 160286. [CrossRef] [PubMed]

73. Dyer, D.P.; Salanga, C.L.; Volkman, B.F.; Kawamura, T.; Handel, T.M. The dependence of chemokine-glycosaminoglycan interactions on chemokine oligomerization. Glycobiology. 2016, 26, 312-326. [CrossRef] [PubMed]

74. Egesten, A.; Eliasson, M.; Johansson, H.M.; Olin, A.I.; Morgelin, M.; Mueller, A.; Pease, J.E.; Frick, I.M.; Bjorck, L. The CXC chemokine MIG/CXCL9 is important in innate immunity against Streptococcus pyogenes. J. Infect. Dis. 2007, 195, 684-693. [CrossRef] [PubMed]

75. Swaminathan, G.J.; Holloway, D.E.; Colvin, R.A.; Campanella, G.K.; Papageorgiou, A.C.; Luster, A.D.; Acharya, K.R. Crystal structures of oligomeric forms of the IP-10/CXCL10 chemokine. Structure 2003, 11, 521-532. [CrossRef] 
76. Dufour, J.H.; Dziejman, M.; Liu, M.T.; Leung, J.H.; Lane, T.E.; Luster, A.D. IFN- $\gamma$-inducible protein 10 (IP-10; CXCL10)-deficient mice reveal a role for IP-10 in effector T cell generation and trafficking. J. Immunol. 2002, 168, 3195-3204. [CrossRef] [PubMed]

77. Casrouge, A.; Decalf, J.; Ahloulay, M.; Lababidi, C.; Mansour, H.; Vallet-Pichard, A.; Mallet, V.; Mottez, E.; Mapes, J.; Fontanet, A.; et al. Evidence for an antagonist form of the chemokine CXCL10 in patients chronically infected with HCV. J. Clin. Investig. 2011, 121, 308-317. [CrossRef] [PubMed]

78. Decalf, J.; Tarbell, K.V.; Casrouge, A.; Price, J.D.; Linder, G.; Mottez, E.; Sultanik, P.; Mallet, V.; Pol, S.; Duffy, D.; et al. Inhibition of DPP4 activity in humans establishes its in vivo role in CXCL10 post-translational modification: Prospective placebo-controlled clinical studies. EMBO Mol. Med. 2016, 8, 679-683. [CrossRef] [PubMed]

79. Campanella, G.S.; Lee, E.M.; Sun, J.; Luster, A.D. CXCR3 and heparin binding sites of the chemokine IP-10 (CXCL10). J. Biol. Chem. 2003, 278, 17066-17074. [CrossRef] [PubMed]

80. Loos, T.; Mortier, A.; Gouwy, M.; Ronsse, I.; Put, W.; Lenaerts, J.P.; Van Damme, J.; Proost, P. Citrullination of CXCL10 and CXCL11 by peptidylarginine deiminase: A naturally occurring posttranslational modification of chemokines and new dimension of immunoregulation. Blood 2008, 112, 2648-2656. [CrossRef] [PubMed]

81. Kuschert, G.S.; Coulin, F.; Power, C.A.; Proudfoot, A.E.; Hubbard, R.E.; Hoogewerf, A.J.; Wells, T.N. Glycosaminoglycans interact selectively with chemokines and modulate receptor binding and cellular responses. Biochemistry 1999, 38, 12959-12968. [CrossRef] [PubMed]

82. Gorrell, M.D.; Gysbers, V.; McCaughan, G.W. CD26: A multifunctional integral membrane and secreted protein of activated lymphocytes. Scand. J. Immunol. 2001, 54, 249-264. [CrossRef] [PubMed]

83. Waumans, Y.; Baerts, L.; Kehoe, K.; Lambeir, A.M.; De Meester, I. The Dipeptidyl Peptidase Family, Prolyl Oligopeptidase, and Prolyl Carboxypeptidase in the Immune System and Inflammatory Disease, Including Atherosclerosis. Front. Immunol. 2015, 6, 387. [CrossRef] [PubMed]

84. Loos, T.; Mortier, A.; Proost, P. Chapter 1. Isolation, identification, and production of posttranslationally modified chemokines. Methods Enzymol. 2009, 461, 3-29. [PubMed]

85. De Meester, I.; Vanhoof, G.; Lambeir, A.M.; Scharpé, S. Use of immobilized adenosine deaminase for the rapid purification of native human CD26/dipeptidyl peptidase IV. J. Immunol. Methods 1996, 189, 99-105. [CrossRef]

86. Grynkiewicz, G.; Poenie, M.; Tsien, R.Y. A new generation of $\mathrm{Ca}^{2+}$ indicators with greatly improved fluorescence properties. J. Biol. Chem. 1985, 260, 3440-3450. [PubMed]

87. Boyden, S. The chemotactic effect of mixtures of antibody and antigen on polymorphonuclear leucocytes. J. Exp. Med. 1962, 115, 453-466. [CrossRef] [PubMed]

88. Janssens, R.; Mortier, A.; Boff, D.; Vanheule, V.; Gouwy, M.; Franck, C.; Larsen, O.; Rosenkilde, M.M.; Van Damme, J.; Amaral, F.A.; et al. Natural nitration of CXCL12 reduces its signaling capacity and chemotactic activity in vitro and abrogates intra-articular lymphocyte recruitment in vivo. Oncotarget 2016, 7, 62439-62459. [CrossRef] [PubMed]

(C) 2017 by the authors. Licensee MDPI, Basel, Switzerland. This article is an open access article distributed under the terms and conditions of the Creative Commons Attribution (CC BY) license (http://creativecommons.org/licenses/by/4.0/). 